Supporting Information for

\title{
Unlocking the Potential of Nanoparticles Composed of Immiscible Elements for Direct $\mathrm{H}_{2} \mathrm{O}_{2}$ Synthesis
}

Donghun Kim, ${ }^{1, \uparrow}$ Hyobin Nam, ${ }^{2,3, \uparrow}$ Young-Hoon Cho, ${ }^{4, \dagger}$ Byung Chul Yeo, ${ }^{1, \dagger}$ So-Hye Cho, ${ }^{2}$ Jae-Pyoung Ahn, ${ }^{5, *}$ Kwan-Young Lee,,${ }^{4, *}$ Seung Yong Lee, ${ }^{2,3, *}$ and Sang Soo Han ${ }^{1, *}$

${ }^{1}$ Computational Science Research Center, Korea Institute of Science and Technology, Seoul 02792, Republic of Korea

${ }^{2}$ Materials Architecturing Research Center, Korea Institute of Science and Technology, Seoul 02792, Republic of Korea

${ }^{3}$ Department of Nanomaterials Science and Engineering, Korea University of Science and Technology, Daejeon 34113, Republic of Korea

${ }^{4}$ Department of Chemical and Biological Engineering, Korea University, Seoul 02841, Republic of Korea

${ }^{5}$ Advanced Analysis Center, Korea Institute of Science and Technology, Seoul 02792, Republic of Korea

*Correspondence to: sangsoo@kist.re.kr (S.S.H); patra@kist.re.kr $\quad$ (S.Y.L); kylee@korea.ac.kr (K.-Y.L); jpahn@kist.re.kr (J.-P. A).

$\dagger$ These authors contributed equally to this work. 
Table S1. Information of used catalyst weight (mg), and composition (A:B ratio) for each catalyst sample.

\begin{tabular}{|c|c|c|c|c|}
\hline \multicolumn{2}{|c|}{ Catalyst (AB) } & $\begin{array}{c}\text { Used Catalyst } \\
\text { weight (mg) }\end{array}$ & $\begin{array}{l}\text { Ratio of initial } \\
\text { loading (A:B) }\end{array}$ & $\begin{array}{c}\text { Real catalytic ratio } \\
\text { A:B (from ICP } \\
\text { measurements) }\end{array}$ \\
\hline \multicolumn{2}{|c|}{$\mathbf{R h}$} & 3.0 & - & - \\
\hline \multicolumn{2}{|c|}{ Ag } & 2.1 & - & - \\
\hline \multicolumn{2}{|c|}{$\mathbf{P t}$} & 1.4 & - & - \\
\hline \multicolumn{2}{|c|}{ Pd } & 3.9 & - & - \\
\hline \multicolumn{2}{|c|}{ Ir } & 4.9 & - & - \\
\hline \multicolumn{2}{|c|}{$\mathbf{A u}$} & 9.6 & - & - \\
\hline \multirow{4}{*}{$\mathbf{R h A g}$} & $\mathbf{R h}_{13} \mathbf{A g}_{87}$ & 5.8 & $10: 90$ & $13: 87$ \\
\hline & $\mathbf{R h}_{26} \mathbf{A g}_{74}$ & 6.5 & $30: 70$ & $26: 74$ \\
\hline & $\mathbf{R h}_{50} \mathrm{Ag}_{50}$ & 6.1 & $65: 35$ & $50: 50$ \\
\hline & $\mathbf{R h}_{69} \mathbf{A g}_{31}$ & 4.9 & $80: 20$ & $69: 31$ \\
\hline \multirow[t]{2}{*}{ RhAu } & $\mathbf{R h}_{46} \mathbf{A u}_{54}$ & 6.6 & $50: 50$ & $46: 54$ \\
\hline & $\mathrm{Pt}_{8} \mathrm{Au}_{92}$ & 1.7 & $10: 90$ & 8:92 \\
\hline \multirow[t]{2}{*}{ PtAu } & $\mathrm{Pt}_{28} \mathrm{Au}_{82}$ & 1.7 & $30: 70$ & $28: 72$ \\
\hline & $\mathrm{Pt}_{42} \mathrm{Au}_{58}$ & 1.7 & $50: 50$ & 42.58 \\
\hline $\operatorname{IrAg}$ & $\operatorname{Ir}_{18} A_{g_{82}}$ & 2.0 & $50: 50$ & 18:82 \\
\hline $\operatorname{IrAu}$ & $\mathbf{I r}_{10} \mathbf{A u}_{90}$ & 8.6 & $50: 50$ & $10: 90$ \\
\hline
\end{tabular}


Table S2. The energetics of each $\mathrm{O}_{2}$ and $\mathrm{H}_{2}$ dissociative adsorption on the (111) surfaces of six pure metals (Ag, Au, Ir, Rh, Pt, and Pd). Our values were all obtained from the revised PBE functional, whereas the references utilized PBE one ${ }^{\mathrm{S} 1, \mathrm{~S} 2}$ or PW91 ${ }^{\mathrm{S} 3, \mathrm{~S} 4, \mathrm{~S} 5}$.

\begin{tabular}{|c|c|c|c|c|}
\hline & \multicolumn{2}{|c|}{$\mathrm{O}_{2}$ dissociation } & \multicolumn{2}{|c|}{$\mathrm{H}_{2}$ dissociation } \\
\hline & $\mathrm{E}\left(\mathrm{O}_{2}{ }^{*} \rightarrow 2 \mathrm{O}^{*}\right)$ & $\mathbf{E}_{\mathbf{a}}\left(\mathrm{O}_{2}{ }^{*} \rightarrow 2 \mathrm{O}^{*}\right)$ & $\mathrm{E}\left(\mathrm{H}_{2}{ }^{*} \rightarrow \mathbf{2 H ^ { * }}\right)$ & $\mathrm{E}_{\mathbf{a}}\left(\mathrm{H}_{2}{ }^{*} \rightarrow 2 \mathrm{H}^{*}\right)$ \\
\hline Ag & $\begin{array}{c}+0.26 \\
\left(+0.19^{\mathrm{S} 3}\right)\end{array}$ & $\begin{array}{c}1.15 \\
\left(1.04^{\mathrm{S} 3}\right)\end{array}$ & +0.76 & 1.71 \\
\hline $\mathbf{A u}$ & $\begin{array}{c}+0.71 \\
\left(+0.74^{\mathrm{S} 3}\right)\end{array}$ & $\begin{array}{c}2.09 \\
\left(1.90^{\mathrm{S} 3}\right)\end{array}$ & $\begin{array}{c}+0.58 \\
\left(+0.50^{\mathrm{S} 2}\right)\end{array}$ & $\begin{array}{c}1.29 \\
\left(1.09^{\mathrm{S} 2}\right)\end{array}$ \\
\hline Ir & $\begin{array}{c}-2.06 \\
\left(-1.92^{\mathrm{S} 4}\right)\end{array}$ & $\begin{array}{c}0.18 \\
\left(0.06^{\mathrm{S} 4}\right)\end{array}$ & $\begin{array}{c}-0.51 \\
\left(-0.81^{\mathrm{S} 2}\right)\end{array}$ & $\begin{array}{c}0.22 \\
\left(0.46^{\mathrm{S} 2}\right)\end{array}$ \\
\hline $\mathbf{R h}$ & -2.35 & 0.23 & -0.54 & 0.02 \\
\hline $\mathbf{P t}$ & -1.39 & $\begin{array}{c}0.70 \\
\left(0.73^{\mathrm{S} 2}\right)\end{array}$ & $\begin{array}{c}-0.42 \\
\left(-0.87^{\mathrm{S} 2}\right)\end{array}$ & $\begin{array}{c}0.17 \\
\left(0.03^{\mathrm{S} 2}\right)\end{array}$ \\
\hline $\mathbf{P d}$ & $\begin{array}{c}-1.66 \\
\left(-1.93^{\mathrm{S} 1}\right) \\
\left(-2.08^{\mathrm{S} 5}\right)\end{array}$ & $\begin{array}{c}1.10 \\
\left(0.97^{\mathrm{S} 1}\right) \\
\left(0.51^{\mathrm{S} 5}\right)\end{array}$ & $\begin{array}{c}-0.92 \\
\left(-1.06^{\mathrm{S} 1}\right)\end{array}$ & $\begin{array}{c}0.17 \\
\left(0.05^{\mathrm{S} 1}\right)\end{array}$ \\
\hline
\end{tabular}




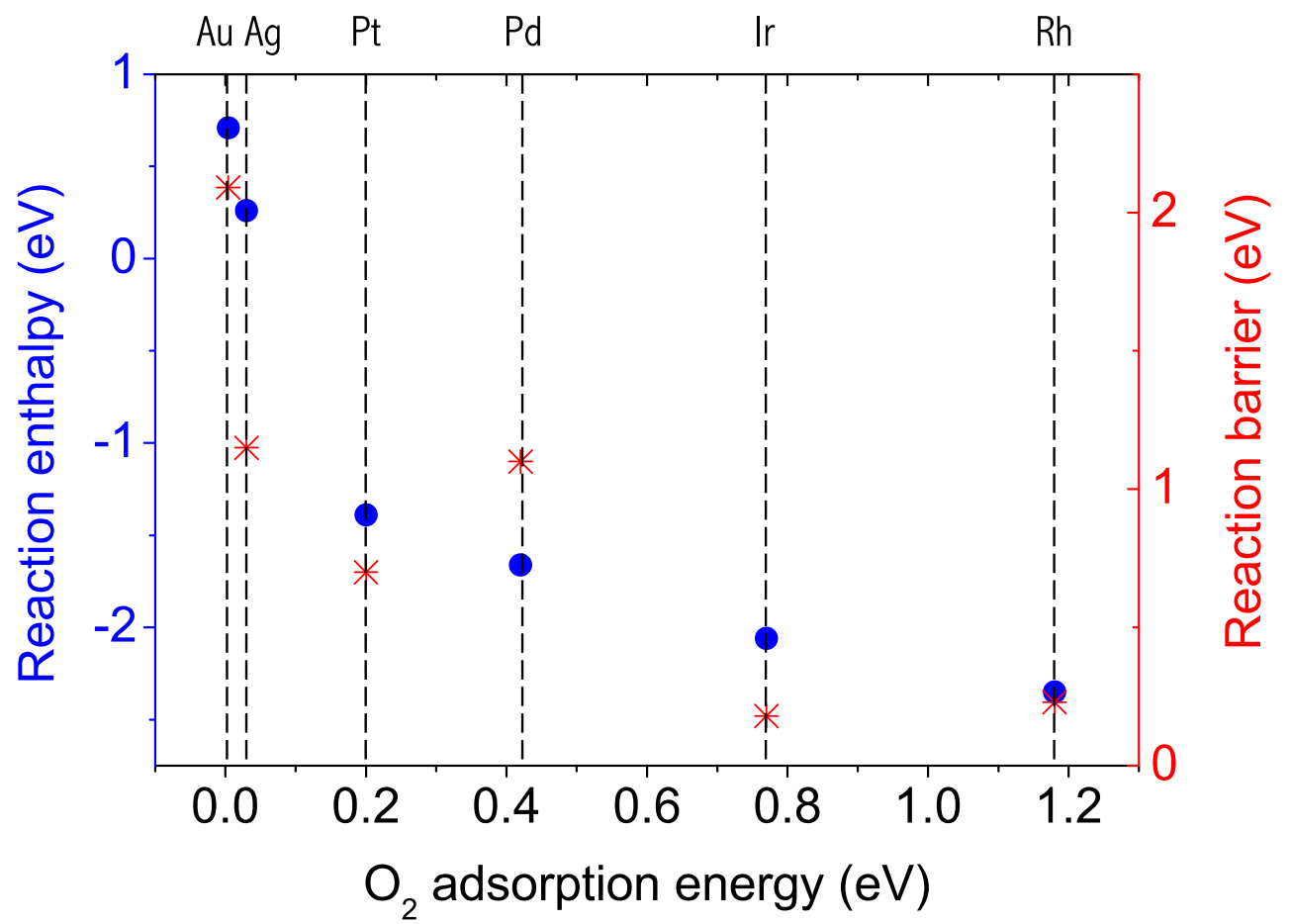

Fig. S1. Correlation between $\mathrm{O}_{2}$ dissociation energetics (reaction enthalpy or barrier) and $\mathrm{O}_{2}$ adsorption energy for the various metals investigated in this work. The stronger the $\mathrm{O}_{2}$ molecules are adsorbed on the metal surface, the more easily the $\mathrm{O}_{2}$ molecules are dissociated into atomic species. 

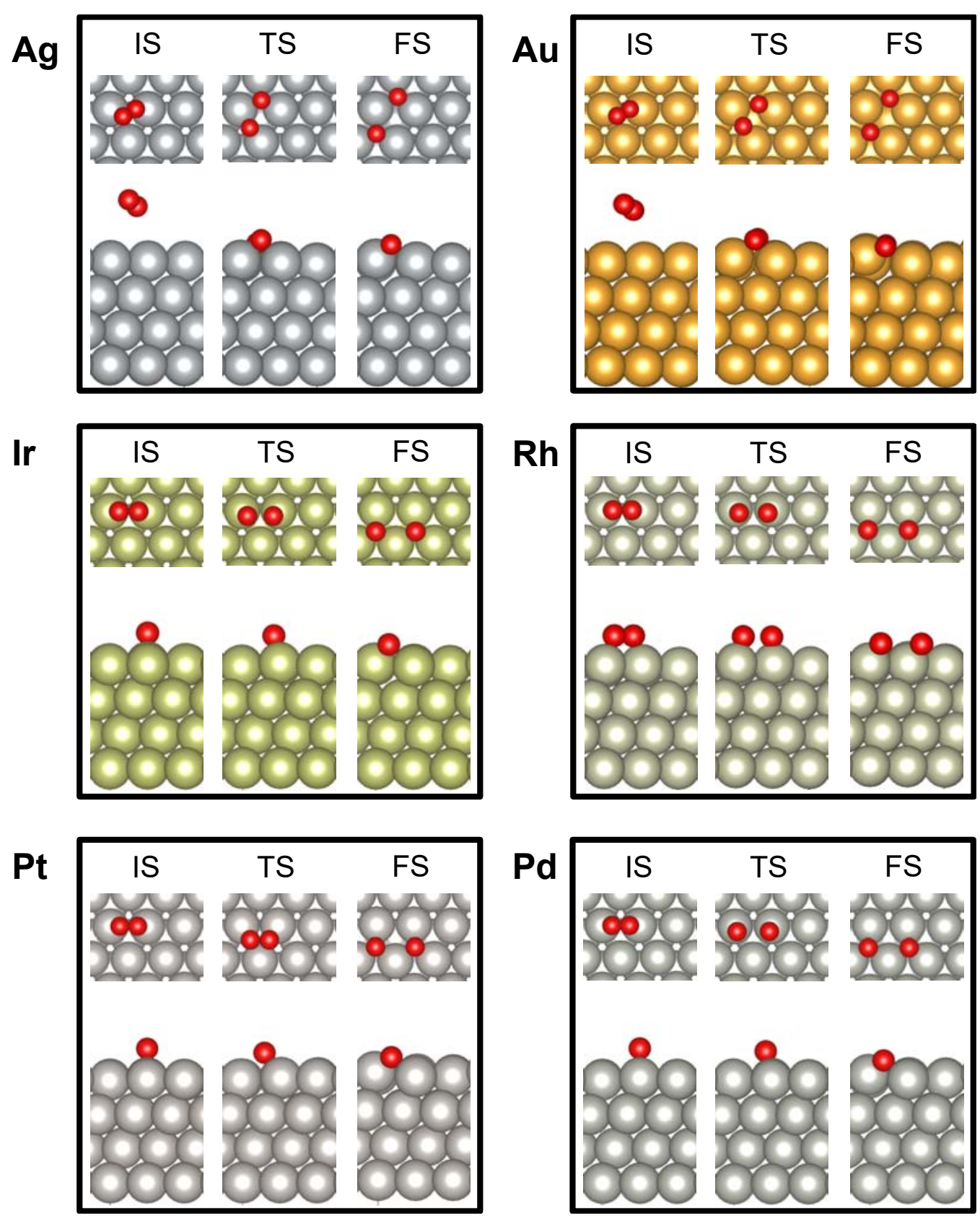

Fig. S2. The geometries of the $\mathrm{O}_{2}$ dissociative adsorptions on the (111) surfaces of six pure metals (Ag, Au, Ir, Rh, Pt, and Pd). Each material set consists of top- and sideview geometries of the initial state (IS), transition state (TS), and final state (FS). Red spheres represent oxygen atoms, and other colors represent metal atoms in the investigation. 

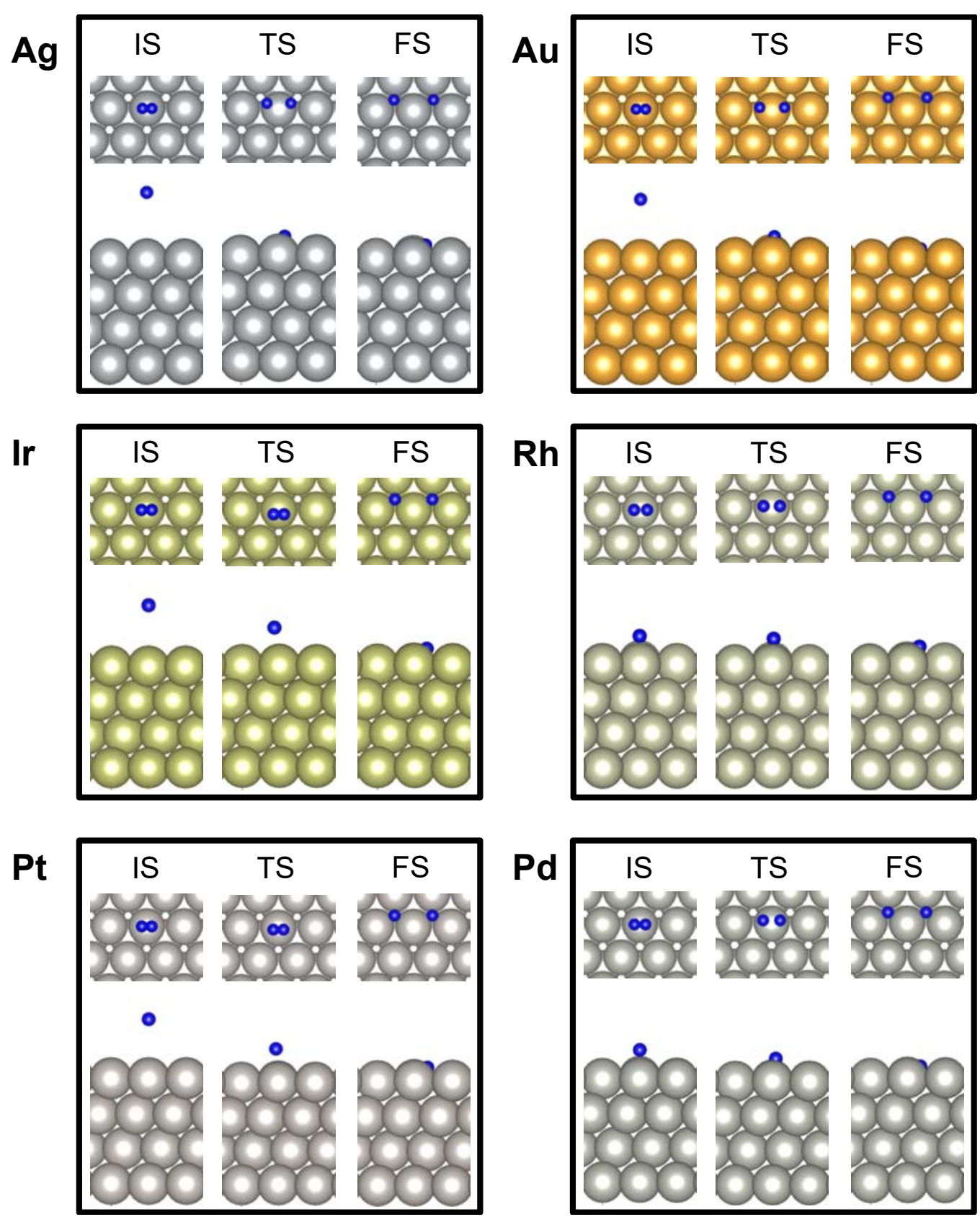

Fig. S3. The geometries of the $\mathrm{H}_{2}$ dissociative adsorptions on the (111) surfaces of six pure metals (Ag, Au, Ir, Rh, Pt, and Pd). Each material set consists of top- and sideview geometries of the initial state (IS), transition state (TS), and final state (FS). Blue spheres represent hydrogen atoms, and other colors represent metal atoms in the investigation. 
Table S3. Migration barriers of $\mathrm{O}_{2}$ and $\mathrm{H}_{2}$ molecules between $\mathrm{Rh}$ and Ag domains. Both $\mathrm{O}_{2}$ and $\mathrm{H}_{2}$ molecules energetically prefer migrating toward $\mathrm{Rh}$ domains $(\mathrm{Ag} \rightarrow \mathrm{Rh})$, compared to the other way $(\mathrm{Rh} \rightarrow \mathrm{Ag})$. These results may seemingly contradict with our initial geometry set-up of $\mathrm{O}_{2}$ and $\mathrm{H}_{2}$ molecules, i.e., $\mathrm{O}_{2}(\mathrm{Ag})-\mathrm{H}_{2}(\mathrm{Rh})$ configuration. This can, however, be justified from a kinetics viewpoint. It is well known that $\mathrm{H}_{2}$ molecules diffuse toward the catalyst surfaces much faster than $\mathrm{O}_{2}$ molecules do due to their smaller

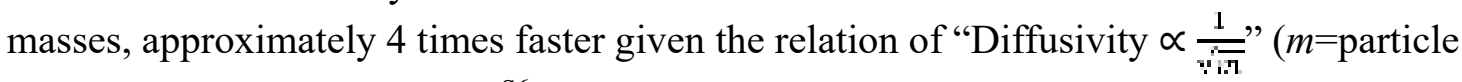
mass, $\left.m_{\text {Oxygen }}=16, m_{\text {Hydrogen }}=1\right)^{\mathrm{S} 6}$. As a result, exposed Rh domains are predominantly covered by $\mathrm{H}_{2}$ molecules. At such a circumstance of $\mathrm{Rh}$ domains being $\mathrm{H}_{2}$-dominated, $\mathrm{O}_{2}$ molecules would reach to Ag domains, causing $\mathrm{O}_{2}(\mathrm{Ag})-\mathrm{H}_{2}(\mathrm{Rh})$ configurations to most likely occur, particularly in the early stages of the $\mathrm{O}_{2} / \mathrm{H}_{2}$ mixture feed.

\begin{tabular}{c|c|c}
\hline \hline & Barrier $\boldsymbol{E}_{\mathbf{a}}$ for $\mathbf{O}_{\mathbf{2}}$ & Barrier $\boldsymbol{E}_{\mathbf{a}}$ for $\mathbf{H}_{\mathbf{2}}$ \\
\hline $\mathbf{R h} \rightarrow \mathbf{A g}$ & $0.57 \mathrm{eV}$ & $0.51 \mathrm{eV}$ \\
\hline $\mathbf{A g} \rightarrow \mathbf{R h}$ & $0.09 \mathrm{eV}$ & $0.14 \mathrm{eV}$ \\
\hline \hline
\end{tabular}


Table S4. Adsorption energies of $\mathrm{O}_{2}-\mathrm{H}_{2}$ pair at different surface coverages. Coverages are shown both in \% unit, and in $\mathrm{O}_{2}-\mathrm{H}_{2}$ pair $\# / \mathrm{nm}^{2}$ unit. Since our DFT model adopted the initial configurations of $\mathrm{O}_{2}(\mathrm{Ag})-\mathrm{H}_{2}(\mathrm{Rh})$, we calculated the adsorption energy per $\mathrm{O}_{2}-\mathrm{H}_{2}$ pair at three surface coverages of $25 \%$ (current model), $50 \%$, and $100 \%$. The average adsorption energy is similarly low $(-0.37 \mathrm{eV})$ at $25 \%$ and $50 \%$; however, it is higher $(-0.22 \mathrm{eV})$ at the denser coverage of $100 \%$ due to stronger molecular interactions; thus, our choice of $25 \%$ coverage in the DFT model is reasonable.

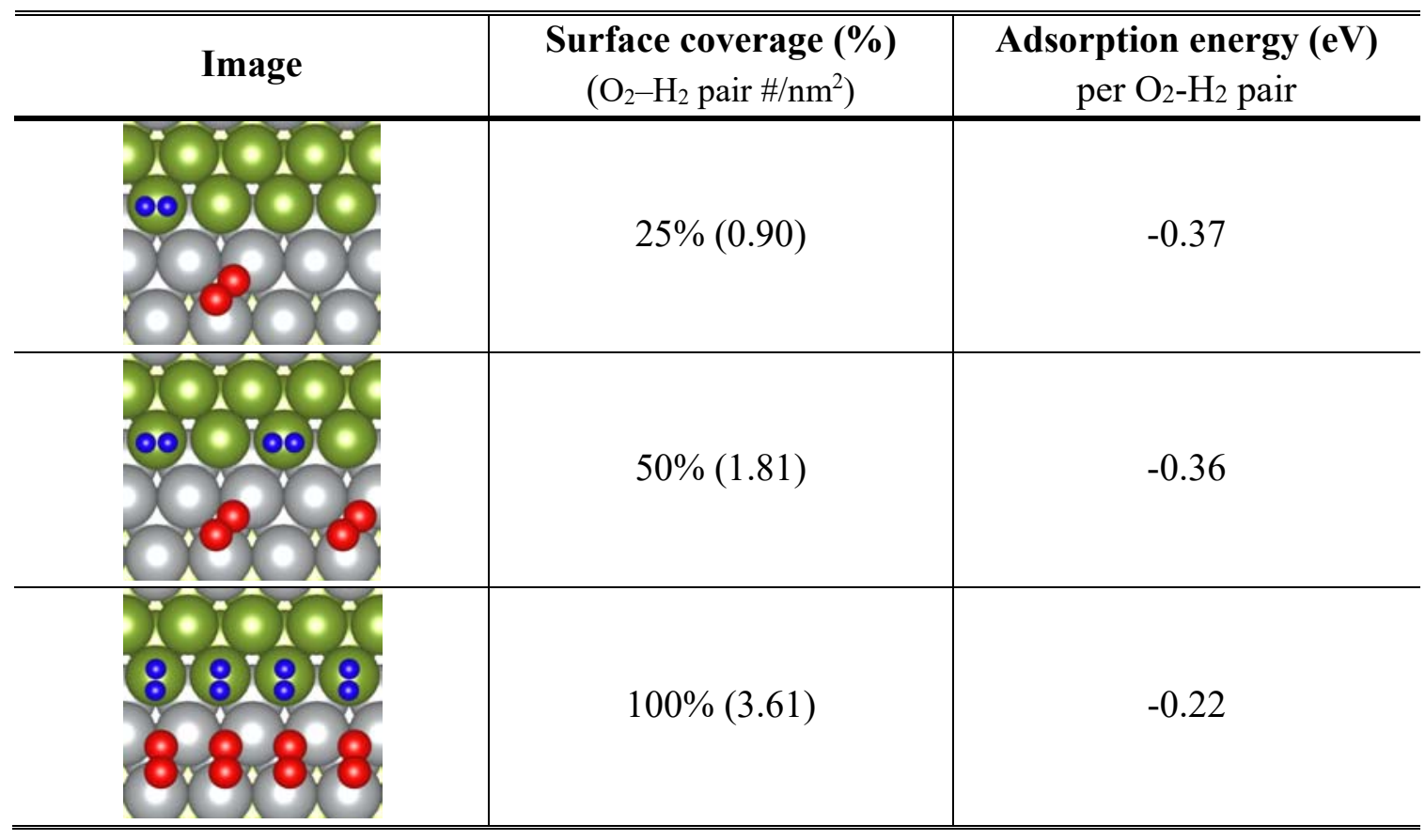



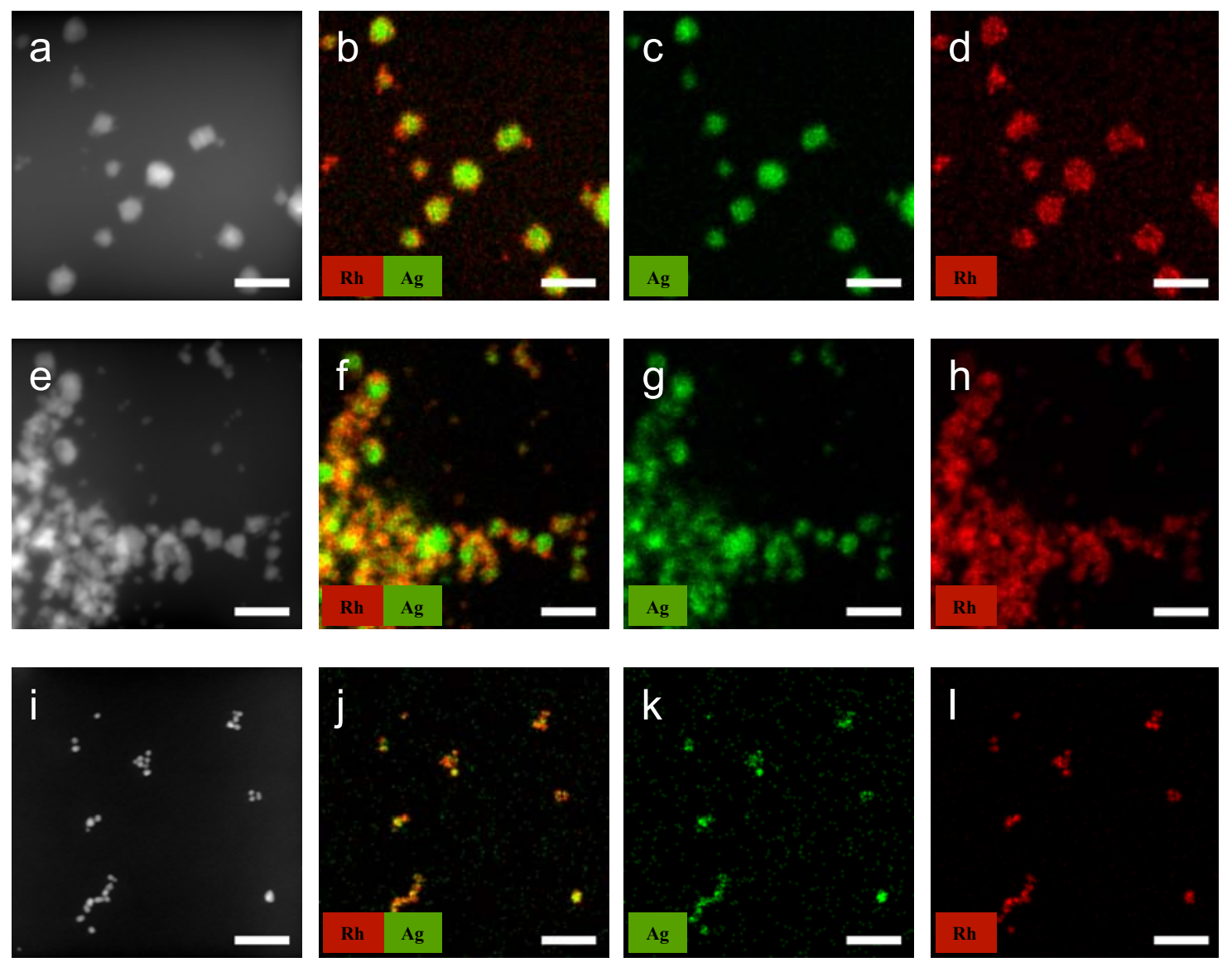

Fig. S4. Structural analysis of the RhAg NPs with different compositions. The representative HAADF grayscale image and EDS (RGB) maps of the collective (a-d) $\mathrm{Rh}_{26} \mathrm{Ag}_{74}$, (e-h) $\mathrm{Rh}_{50} \mathrm{Ag}_{50}$, and (i-1) $\mathrm{Rh}_{69} \mathrm{Ag}_{31}$ NPs. Scale bars in the images and maps represent $20 \mathrm{~nm}$. 
(A) $\mathrm{Rh}_{13} \mathrm{Ag}_{87} \mathrm{NPs}$ (our sample)
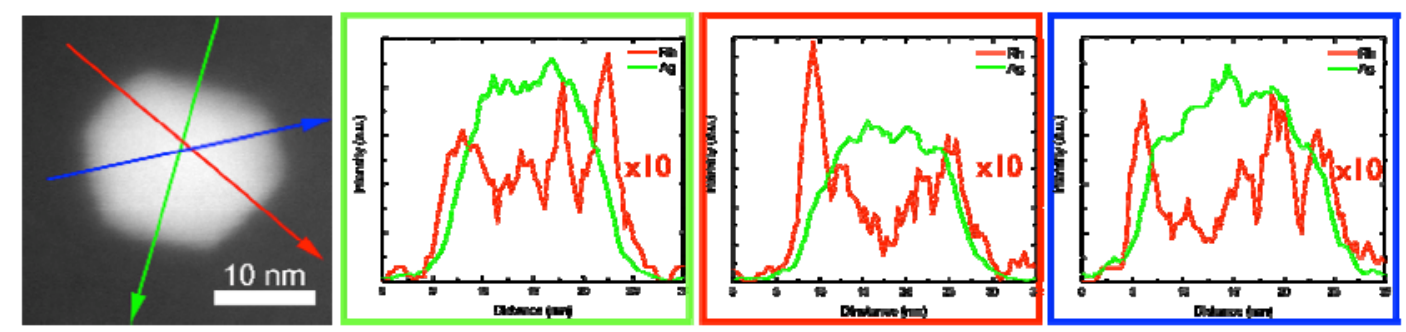

(B) $\mathrm{Rh}_{26} \mathrm{Ag}_{74} \mathrm{NPs}$ (our sample)
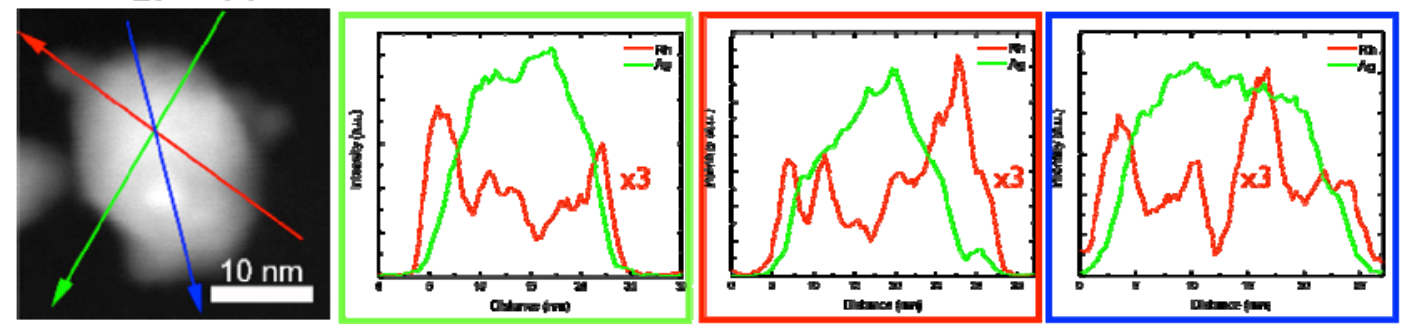

Fig. S5. EDS line-scan images of our RhAg NPs. (A) line-scan images of $\mathrm{Rh}_{13} \mathrm{Ag} 87 \mathrm{NPs}$ ( $\mathrm{Rh}$ profile $\times 10$ amplified, for clarity). (B) line-scan images of $\mathrm{Rh}_{26} \mathrm{Ag}_{74} \mathrm{NPs}$ ( $\mathrm{Rh}$ profile $\times 3$ amplified, for clarity). A prominent difference between $\mathrm{Ag}$ and $\mathrm{Rh}$ profiles is observed: Ag profiles are Gaussian-distribution-like, whereas Rh profiles irregularly fluctuate. This result is consistent with our claim on NP structure that Ag forms the core of NPs and Rh islands of different sizes sit on the Ag cores in a random manner. 
(A) $\mathrm{Rh}_{13} \mathrm{Ag}_{87} \mathrm{NPs}$

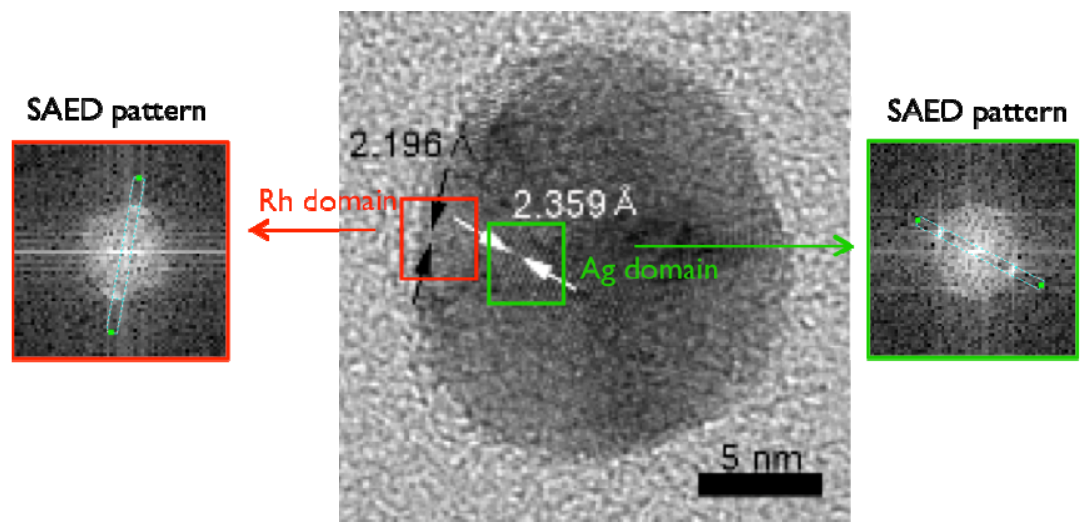

(B) $\mathrm{Rh}_{26} \mathrm{Ag}_{74} \mathrm{NPs}$

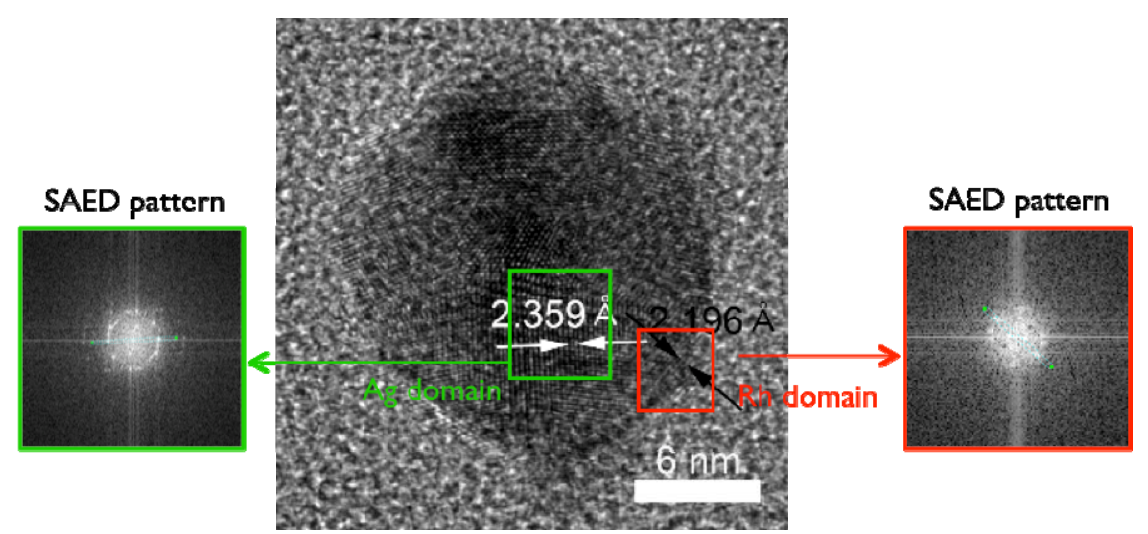

Fig. S6. SAED pattern analysis of (A) $\operatorname{Rh}_{13} A g_{87} \mathrm{NPs}$ and (B) $\operatorname{Rh}_{26} \mathrm{Ag}_{74} \mathrm{NPs}$. 


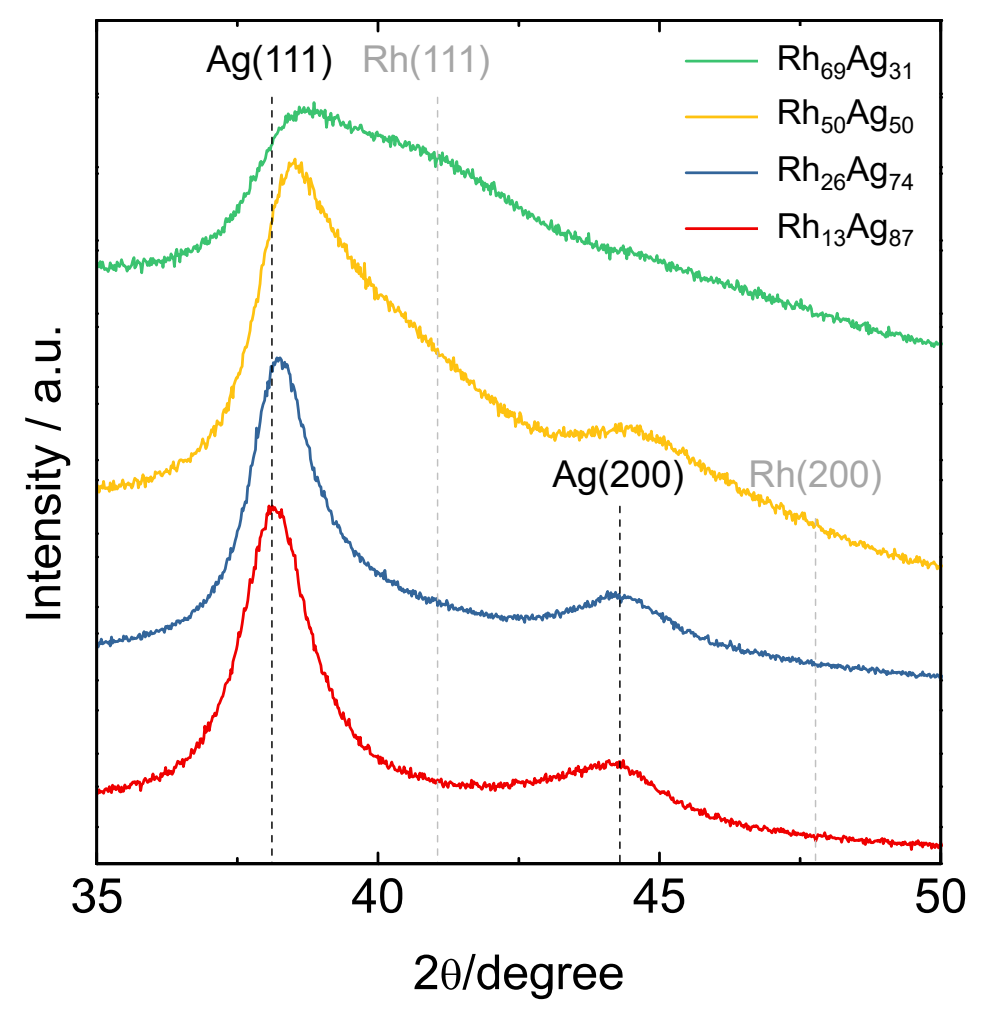

Fig. S7. XRD spectra of the RhAg NPs with different compositions. At low Rh contents (26\% and below), the dominant peaks of the RhAg NPs align with those of pure $\mathrm{Ag}$, indicating that homogeneous mixtures of $\mathrm{Rh}$ and $\mathrm{Ag}$ did not form. Peaks corresponding to pure $\mathrm{Rh}$ are not observed because $\mathrm{Rh}$ is present in amorphous phases. As the $\mathrm{Rh}$ content increases ( $50 \%$ and above), individual crystalline $\mathrm{Rh}$ domains develop; as a result, $\mathrm{Rh}$ peaks for the (111) planes $\left(2 \theta\right.$ of $\left.41.06^{\circ}\right)$ emerge, and the $\operatorname{Ag}(111)$ peaks slightly shift to larger angles. 


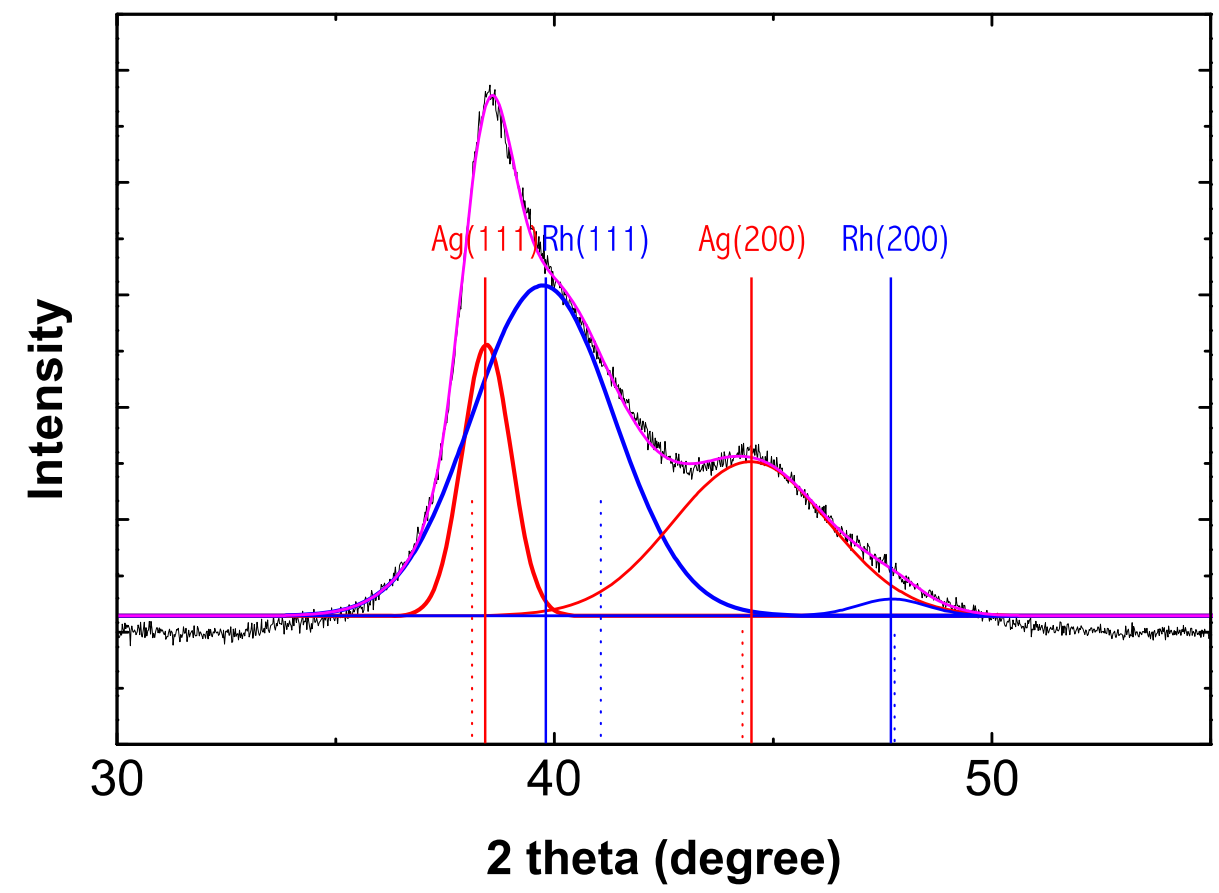

Fig. S8. XRD peak-deconvolution results of the $\mathbf{R h}_{50} \mathbf{A g}_{50}$ NP sample. Peak positions of the pure metals (JCPDS) are also shown as comparisons, and denoted by dashed lines: $\operatorname{Ag}(111)$ at $38.1^{\circ}, \operatorname{Rh}(111)$ at $41.1^{\circ}, \operatorname{Ag}(200)$ at $44.3^{\circ}$, and $\mathrm{Rh}(200)$ at $47.8^{\circ}$. While no shift was found for low Rh-content samples ( $\mathrm{Rh}_{13} \mathrm{Ag}_{87}$ or $\mathrm{Rh}_{26} \mathrm{Ag}_{74} \mathrm{NPs}$ ), a small peakshift was indeed observed for Rh-rich samples $(\mathrm{Rh} \geq 50 \%)$. We performed the XRD deconvolution analysis of the $\mathrm{Rh}_{50} \mathrm{Ag}_{50}$ sample. One can see that the $\operatorname{Ag}(111)$ peak is shifted by $+0.3^{\circ}, \operatorname{Rh}(111)$ peak is shifted by $-1.3^{\circ}$, and $\operatorname{Ag}(200)$ and $\operatorname{Rh}(200)$ peaks are negligibly shifted, all compared to JCPDS positions. Though the shifts are overall small, these indicate a sign that the "partial alloying" occurred at the nanoscale in the $\mathrm{Rh}_{50} \mathrm{Ag}_{50}$ sample. However, it is very important to note that lower $\mathrm{Rh}$-content samples $(\mathrm{Rh} \leq 26 \%)$, which exhibits comparatively much higher $\mathrm{H}_{2} \mathrm{O}_{2}$ production rates, do not show any signs of alloying in XRD; thus, $\mathrm{H}_{2} \mathrm{O}_{2}$ productions in our samples are not a result of alloying. The key conclusions of the present study are still solid. 


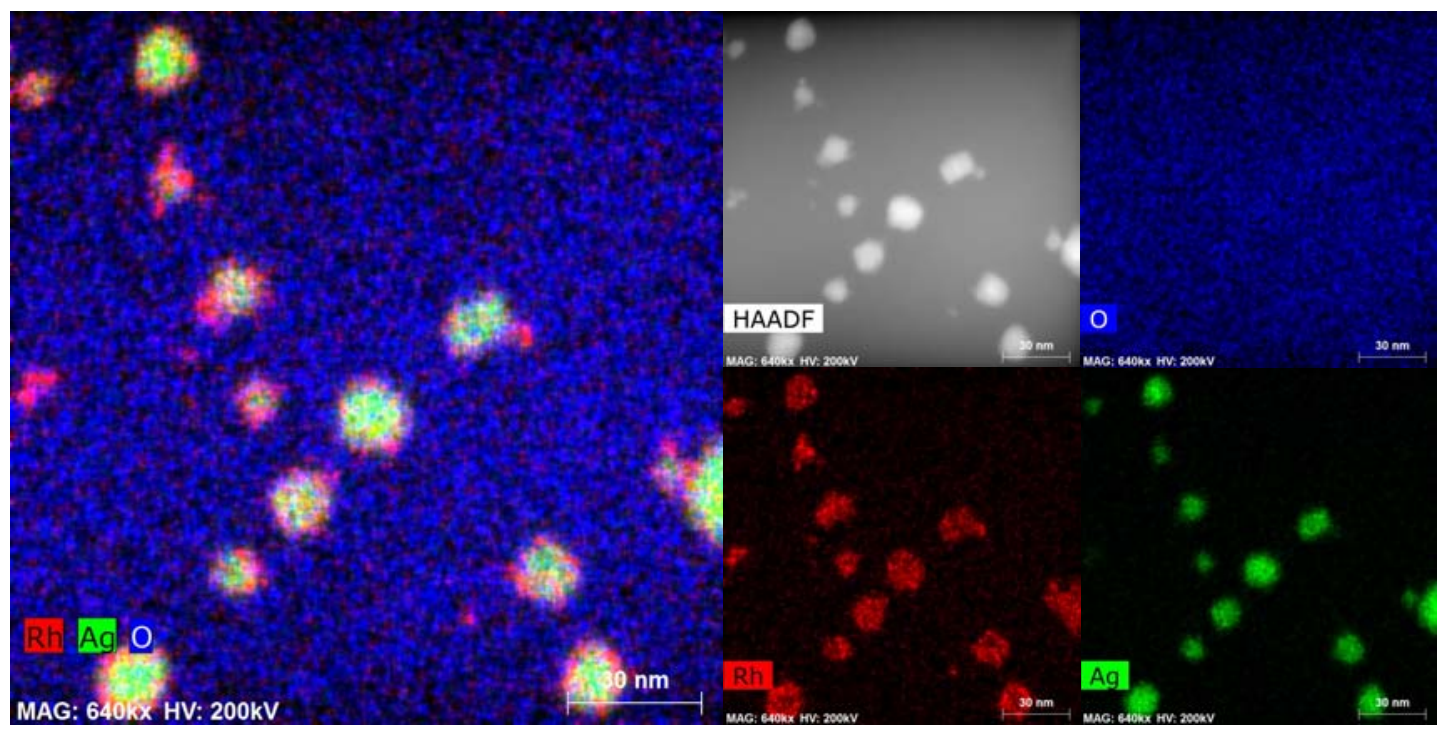

Fig. S9. The representative HAADF grayscale image and the corresponding EDS (RGB) maps of the collective $\mathbf{R h}_{26} \mathbf{A g}_{74}$ NPs. The qualitative elemental distributions of $\mathrm{Rh}, \mathrm{Ag}$, and $\mathrm{O}$ are represented in red, green, and blue, respectively. However, oxygen was observed at noise-level over the entire background; thus, it was extremely difficult to identify whether $\mathrm{Rh}$ is oxidized from EDS results. 


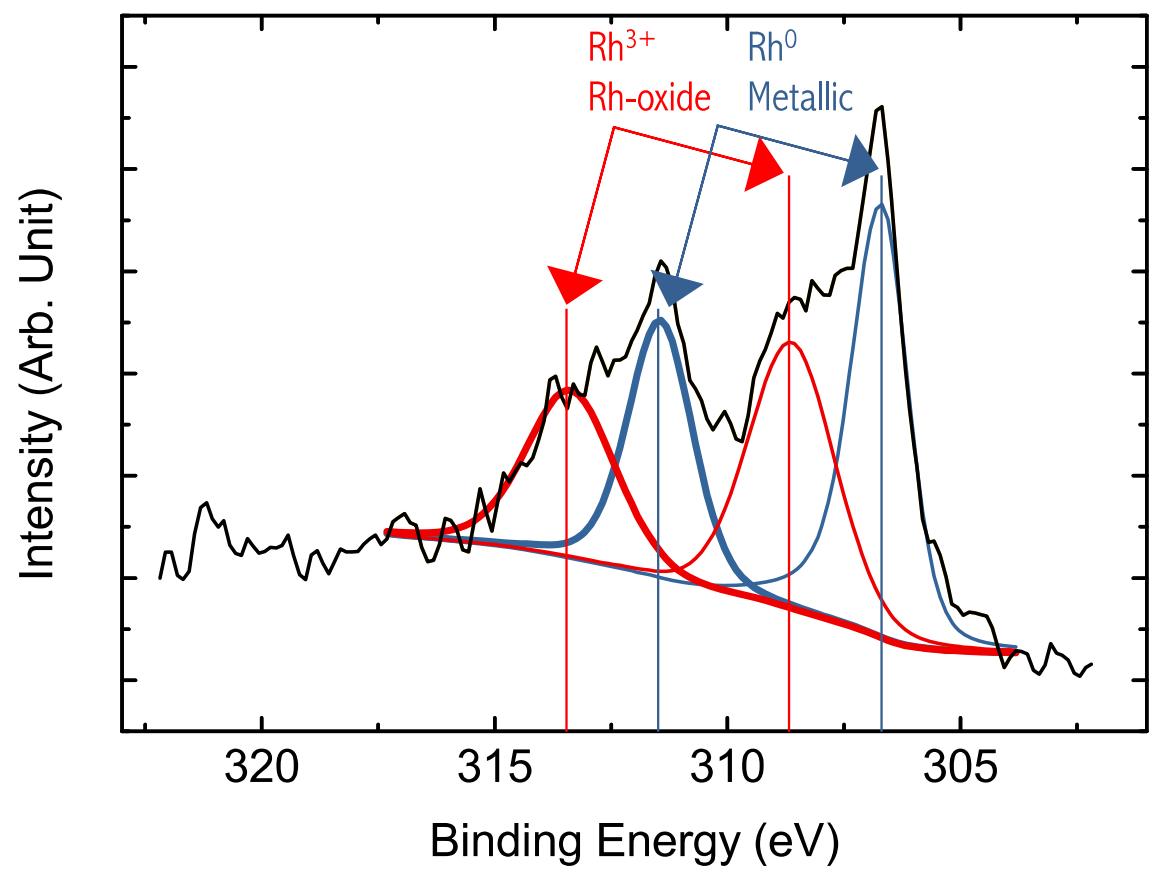

Fig. S10. XPS spectra and the deconvolution (curve-fitting) results of $\mathbf{R h} \mathbf{3 d}$ of $\mathbf{R h}_{26} \mathbf{A g}_{74}$. The peaks of $\mathrm{Rh}^{3+}$ and $\mathrm{Rh}^{0}$ are shown in red and blue, respectively. XPS is a suitable method to identify whether Rh is oxidized and, further, to quantify the degree of oxidation. Taking the $\mathrm{Rh}_{26} \mathrm{Ag}_{74}$ sample as an example, we observe and estimate approximately $46 \% \mathrm{Rh}^{3+}$ peaks (as in $\mathrm{Rh}_{2} \mathrm{O}_{3}$ ), which indicates $\mathrm{Rh}$ is partially oxidized. 
Table S5. A comparison of catalytic performance of unsupported and silicasupported Pd NP. All catalytic test conditions are identical: T, $20^{\circ} \mathrm{C} ; \mathrm{P}, 1 \mathrm{~atm}$; reaction medium, $150 \mathrm{ml}$ of a DI water mixture $\left(20 \%\right.$ ethanol, $0.9 \mathrm{mM} \mathrm{KBr}$, and $\left.0.03 \mathrm{M} \mathrm{H}_{3} \mathrm{PO}_{4}\right)$; total flow rate, $22 \mathrm{ml} / \mathrm{min} ; \mathrm{H}_{2} / \mathrm{O}_{2}, 1 / 10$.

\begin{tabular}{l|c|c}
\hline \hline & Fresh Pd catalyst & $\begin{array}{c}\text { Pd/SiO } \text { catalyst } \\
\text { (Change in \%, compared to fresh } \\
\text { catalyst) }\end{array}$ \\
\hline Productivity $\left(\mathrm{mmol} \mathrm{g}^{-1} \mathrm{~h}^{-1}\right)$ & 59 & $48(-18 \%)$ \\
\hline Selectivity (\%) & 39 & $36(-7 \%)$ \\
\hline $\mathrm{H}_{2}$ conversion (\%) & 11 & $7(-36 \%)$ \\
\hline \hline
\end{tabular}


Table S6. Catalytic performances of all the NPs investigated in the present work.

The cost-normalized productivity (CNP) was calculated to compare the cost-effectiveness of the developed catalyst materials. Reactions were carried out under the following conditions: $\mathrm{T}, 20^{\circ} \mathrm{C} ; \mathrm{P}, 1 \mathrm{~atm}$; reaction medium, $150 \mathrm{ml}$ of DI water mixture $(20 \%$ ethanol, $0.9 \mathrm{mM} \mathrm{KBr}, 0.03 \mathrm{M} \mathrm{H}_{3} \mathrm{PO}_{4}$ ); reaction time, $1 \mathrm{~h}$; total flow rate, $22 \mathrm{ml} / \mathrm{min}$; $\mathrm{H}_{2} / \mathrm{O}_{2}, 1 / 10$. For Pd NPs, several literature values are also shown for comparison ${ }^{\mathrm{S} 7, \mathrm{~S} 8, \mathrm{~S} 9}$.

\begin{tabular}{|c|c|c|c|c|c|}
\hline \multicolumn{2}{|c|}{ Catalyst } & \multirow{2}{*}{$\frac{\begin{array}{c}\mathrm{H}_{2} \mathrm{O}_{2} \\
\left(\mathbf{m m o l ~ g r o d u c t i v i t y}^{-1} \mathbf{h}^{-1}\right)\end{array}}{66}$} & \multirow{2}{*}{$\begin{array}{c}\begin{array}{c}\mathrm{H}_{2} \mathrm{O}_{2} \\
\text { productivity } \\
\left(\mathbf{C N P}, \mathbf{m m o l}^{-1}\right. \\
\left.\text { \$cat }^{-1} \mathbf{h}^{-1}\right)\end{array} \\
\text { N/A }\end{array}$} & \multirow{2}{*}{$\begin{array}{c}\begin{array}{c}\mathbf{H}_{2} \\
\text { conversion } \\
(\%)\end{array} \\
7\end{array}$} & \multirow{2}{*}{$\begin{array}{c}\begin{array}{c}\mathrm{H}_{2} \mathbf{O}_{2} \\
\text { selectivity } \\
(\%)\end{array} \\
39.5\end{array}$} \\
\hline & $\operatorname{Pd}(\text { cube })^{\mathrm{S} 8}$ & & & & \\
\hline Pd NPs & Pd (cube) $)^{\mathrm{S} 9}$ & 86 & N/A & 10 & 30 \\
\hline \multirow[t]{2}{*}{ (Literature) } & $\operatorname{Pd}(\text { octa) })^{\mathrm{S} 10}$ & 106 & N/A & 10.5 & 41.5 \\
\hline & $\mathbf{P d}^{\mathrm{S7}}$ & 31 & N/A & 29 & 21 \\
\hline \multicolumn{2}{|c|}{ Pd } & 59 & 1.8 & 11.7 & 39 \\
\hline \multicolumn{2}{|c|}{ Ag } & 0 & 0 & 0 & 0 \\
\hline \multicolumn{2}{|c|}{ Au } & 0 & 0 & 1.3 & 0 \\
\hline \multicolumn{2}{|c|}{$\mathbf{R h}$} & 0 & 0 & 0.4 & 0 \\
\hline \multicolumn{2}{|c|}{ Ir } & 0 & 0 & 0.6 & 0 \\
\hline \multicolumn{2}{|c|}{$\mathbf{P t}$} & 20 & 0.7 & 10.9 & 4 \\
\hline \multirow{5}{*}{ RhAg NPs } & $\mathbf{R h}_{5} \mathbf{A g}_{95}$ & 0 & 0 & 0.2 & 0 \\
\hline & $\mathbf{R h}_{13} \mathbf{A g}_{87}$ & 67 & 13.3 & 3.2 & 62 \\
\hline & $\mathbf{R h}_{26} \mathbf{A g}_{74}$ & 30 & 2.1 & 2.4 & 78 \\
\hline & $\mathbf{R h}_{50} \mathbf{A g}_{50}$ & 8 & 0.3 & 5.1 & 16 \\
\hline & $\mathbf{R h}_{69} \mathbf{A g}_{31}$ & 0 & 0 & 0.4 & 0 \\
\hline \multicolumn{2}{|c|}{$\mathbf{R h}_{46} \mathbf{A u}_{54}$} & 56 & 1.3 & 3.0 & 37 \\
\hline \multirow{3}{*}{ PtAu NPs } & $\mathrm{Pt}_{8} \mathrm{Au}_{92}$ & 103 & 2.6 & 9.0 & 39 \\
\hline & $\mathbf{P t}_{28} \mathrm{Au}_{72}$ & 300 & 8.0 & 28.0 & 36 \\
\hline & $\mathbf{P t}_{42} \mathrm{Au}_{58}$ & 237 & 6.6 & 21.9 & 13 \\
\hline \multicolumn{2}{|c|}{$\operatorname{Ir}_{18} \mathbf{A g}_{82}$} & 13 & 0.8 & 2.9 & 18 \\
\hline \multicolumn{2}{|c|}{$\operatorname{Ir}_{10} A u 90$} & 0 & 0 & 5.6 & 0 \\
\hline
\end{tabular}



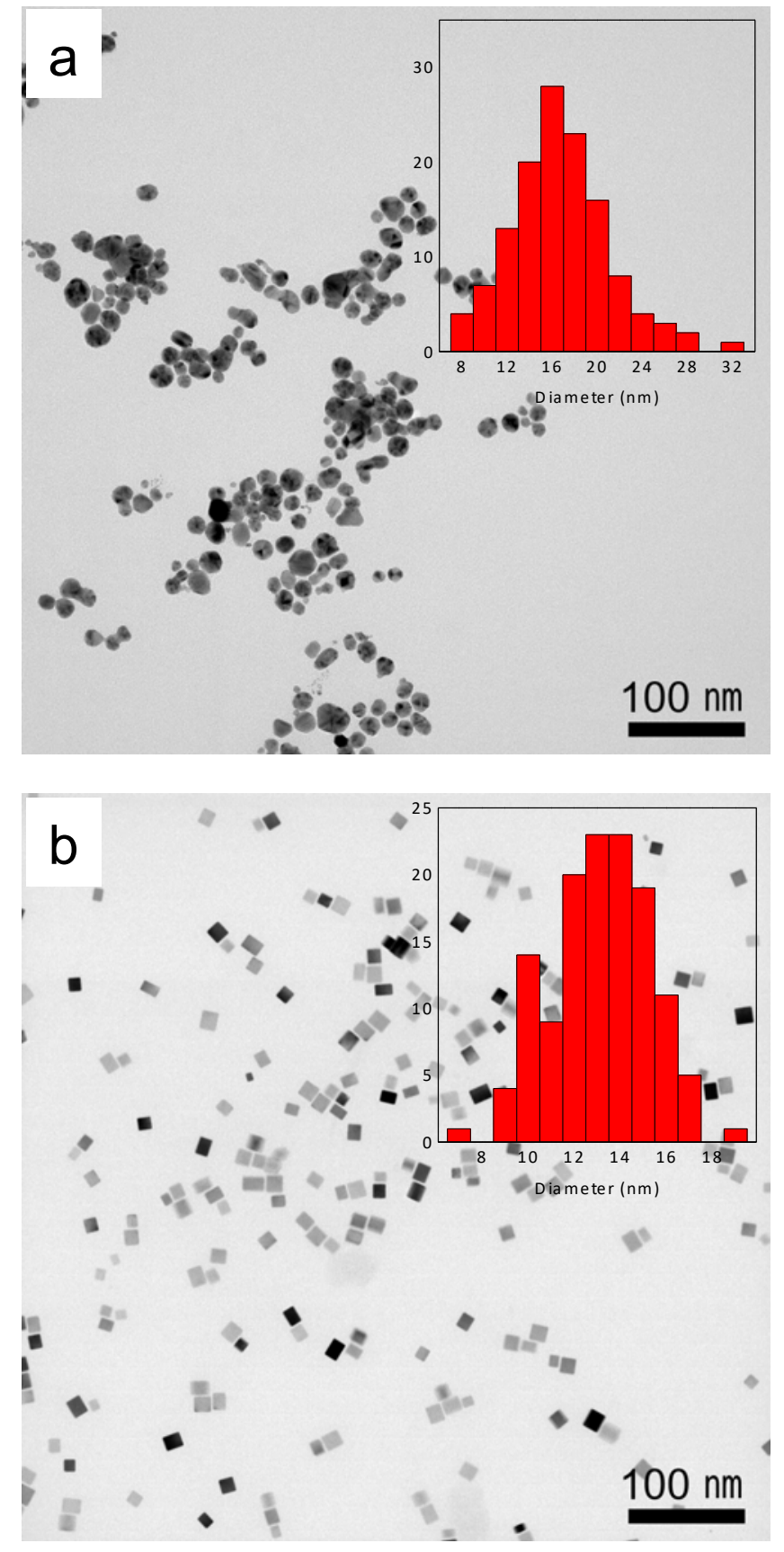

Fig. S11. TEM images of the (a) $\mathbf{R h}_{10} \mathbf{A g}_{90}$ NPs and (b) Pd NPs. While the RhAg NPs develop spherical shapes, the Pd NPs form perfect cube shapes with the (100) surfaces exposed. The particle size distributions are also shown in the inset of each image.

$\mathrm{Rh}_{10} \mathrm{Ag}_{90}$ NPs synthesized from the polyol reduction method are primarily sphere-shaped with the average diameter $(d)$ of $15.74 \mathrm{~nm}$, while Pd NPs are cube-shaped with the average side length $(l)$ of $12.58 \mathrm{~nm}$. Given 1 gram of metal loading, total surface area $(\boldsymbol{S})$ can be calculated as follows: (1) $S$ of Pd cube NPs: $N_{\mathrm{Pd}} \times 6 l^{2}=\left(1 \mathrm{gram} / \rho_{\mathrm{Pd}} \cdot l^{3}\right) \times 6 l^{2}=3.76 \times 10^{19}$ 
$\left(\mathrm{nm}^{2}\right)$, (2) $\boldsymbol{S}$ of $\mathrm{Rh}_{10} \mathrm{Ag}_{90}$ spherical NPs: $N_{\mathrm{RhAg}} \times \pi d^{2}=\left[1 \mathrm{gram} / \rho_{\mathrm{RhAg}} \cdot\left(\pi d^{3} / 6\right)\right] \times \pi d^{2}=3.57 \times 10^{19}$ $\left(\mathrm{nm}^{2}\right)$, where $N_{\mathrm{Pd}}, N_{\mathrm{RhAg}}$ is the number of Pd and RhAg NPs in total $1 \mathrm{~g}$ metal loading, respectively, and $\rho_{\mathrm{Pd}}, \rho_{\mathrm{RhAg}}$ is the effective density of $\mathrm{Pd}\left(12.68 \mathrm{~g} / \mathrm{cm}^{3}\right)$ and $\mathrm{Rh}_{10} \mathrm{Ag}_{90}\left(10.68 \mathrm{~g} / \mathrm{cm}^{3}\right)$, respectively. One can observe from the above comparisons that the cubed Pd NPs have a very similar surface area to our RhAg NPs (less than 5\% difference) and therefore can serve as a great reference system. In contrast to the cubed Pd NPs, we observed that spherical Pd NPs could be formed only with a much smaller NP diameter $(d<8 \mathrm{~nm})$; thus, direct comparisons of our samples with spherical Pd NPs are difficult, as the total surface areas differ too much. 
(a)

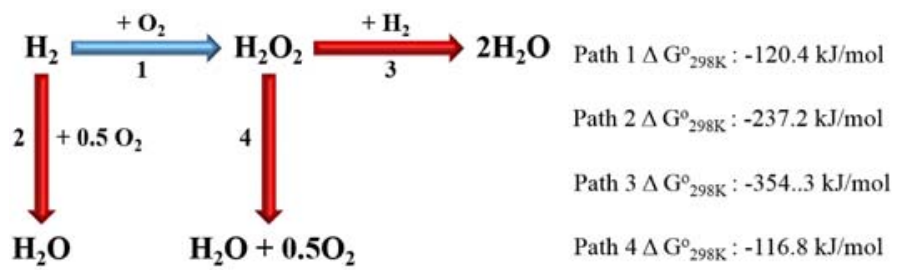

(b)

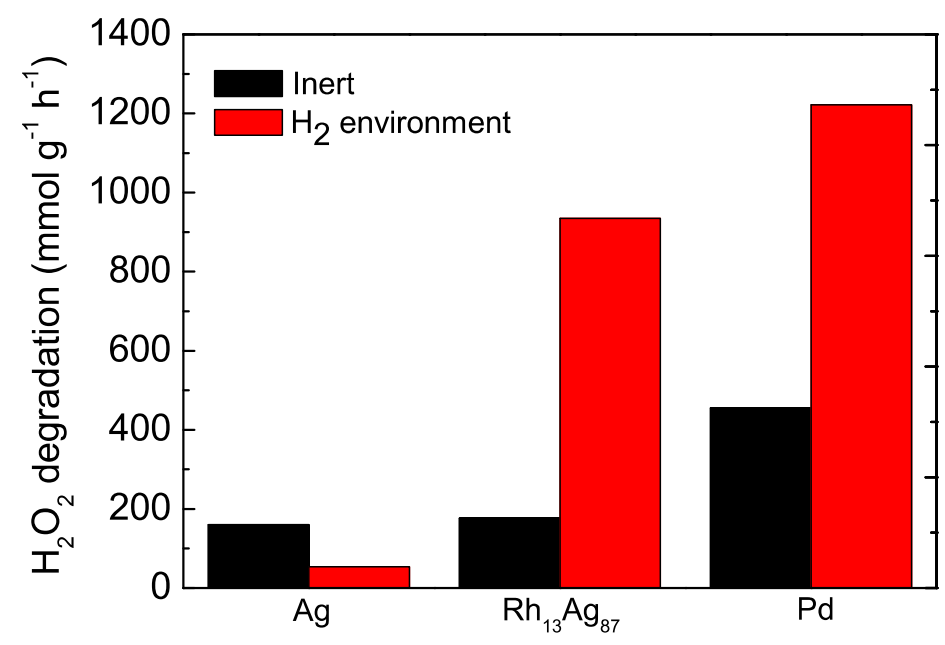

Fig. S12. $\mathrm{H}_{2} \mathrm{O}_{2}$ degradation tests of $\mathrm{Rh}_{13} \mathrm{Ag}_{87} \mathrm{NPs}$ under both inert and $\mathrm{H}_{2}$ containing atmospheres in comparisons to pure Ag and Pd NPs. (a) A schematic flow of direct $\mathrm{H}_{2} \mathrm{O}_{2}$ synthesis and degradation. Steps 3 and 4 represent $\mathrm{H}_{2} \mathrm{O}_{2}$ degradation under $\mathrm{H}_{2}$-containing and inert environments, respectively. (b) $\mathrm{H}_{2} \mathrm{O}_{2}$ decomposition test results, shown in units of $\mathrm{mmol} \mathrm{g}^{-1} \mathrm{~h}^{-1}$. The reaction conditions are as follows: $\mathrm{T}, 20^{\circ} \mathrm{C} ; \mathrm{P}, 1 \mathrm{~atm}$; $1 \mathrm{ml}$ of $\mathrm{H}_{2} \mathrm{O}_{2}\left(35 \mathrm{wt} \%\right.$ in $\left.\mathrm{H}_{2} \mathrm{O}\right)$; reaction medium, $150 \mathrm{ml}$ of a $0.03 \mathrm{M} \mathrm{H}_{3} \mathrm{PO}_{4} 20$ vol.\% ethanolic solution with $0.09 \mathrm{mM} \mathrm{KBr}$; total flow rate, $22 \mathrm{ml} / \mathrm{min}$; time, $1 \mathrm{~h}$. For the hydrogenation reaction, $\mathrm{H}_{2} / \mathrm{N}_{2}=1 / 10$ was used. 
a

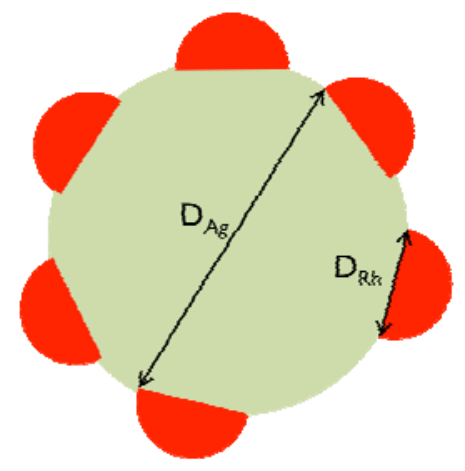

C

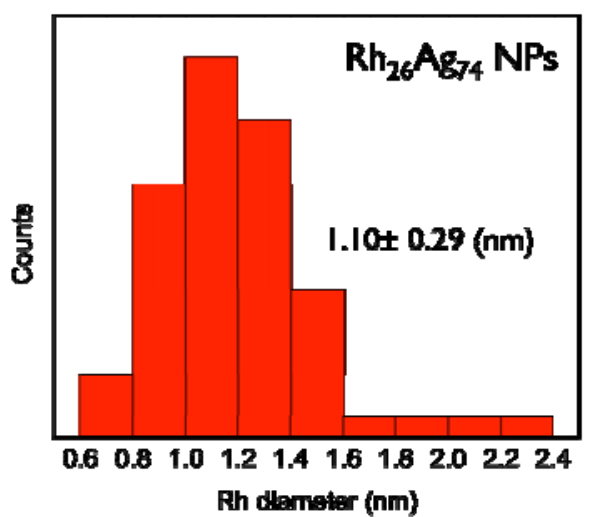

b

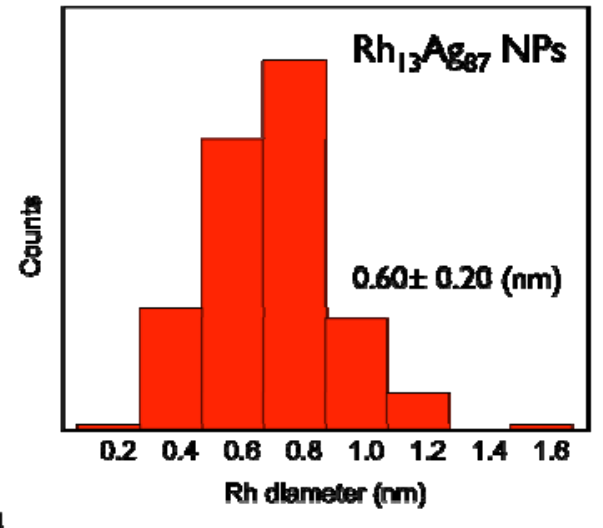

d

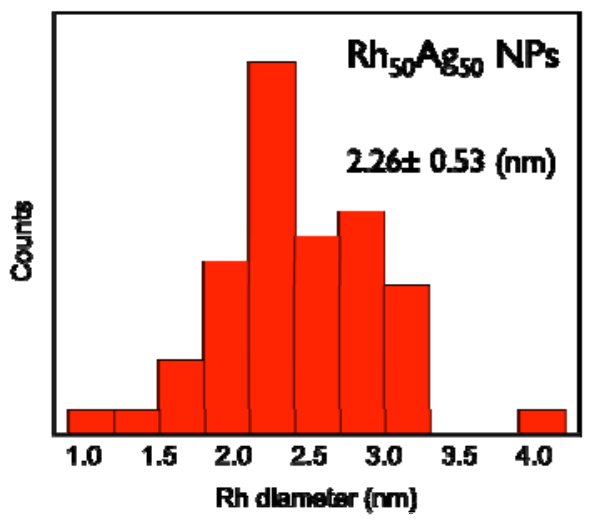

Fig. S13. A schematic of our representative NPs and Rh particle size distributions. a. A model schematic for estimating interfacial length. b-d. Histograms showing Rh particle size (diameter) distributions for $\mathrm{Rh}_{13} \mathrm{Ag}_{87}, \mathrm{Rh}_{26} \mathrm{Ag}_{74}$, and $\mathrm{Rh}_{50} \mathrm{Ag}_{50} \mathrm{NPs}$. 
Table S7. Interfacial length estimations of RhAg NPs of different compositions. The diameter of $\mathrm{Rh}$ clusters is averaged over 100 samples. The numbers in the parentheses are values of standard deviations. The details of the model to estimate interfacial length are elaborated as follows.

\begin{tabular}{c|c|c|c|c|c}
\hline \hline Materials & $\mathbf{D}_{\mathrm{Rh}}, \mathrm{nm}$ & $\begin{array}{c}\text { Interfacial } \\
\text { length, } \\
\mathbf{1 0}^{\mathbf{2 0}} \mathbf{n m} / \mathbf{g}_{\text {cat }}\end{array}$ & $\begin{array}{c}\text { Interfacial } \\
\text { length } \\
\text { (normalized to } \\
\text { the largest) }\end{array}$ & $\begin{array}{c}\text { Productivity, } \\
\mathbf{m m o l} / \mathbf{g}_{\text {cat }} \mathbf{h}\end{array}$ & $\begin{array}{c}\text { Productivity } \\
\text { (normalized to } \\
\text { the largest) }\end{array}$ \\
\hline $\mathrm{Rh}_{13} \mathrm{Ag}_{87} \mathrm{NPs}$ & $0.60( \pm 0.20)$ & $3.49( \pm 1.16)$ & 1.0 & 67.4 & 1.0 \\
\hline $\mathrm{Rh}_{26} \mathrm{Ag}_{74} \mathrm{NPs}$ & $1.10( \pm 0.29)$ & $2.08( \pm 0.55)$ & 0.60 & 30.0 & 0.45 \\
\hline $\mathrm{Rh}_{50} \mathrm{Ag}_{50} \mathrm{NPs}$ & $2.26( \pm 0.53)$ & $0.95( \pm 0.22)$ & 0.27 & 7.5 & 0.11 \\
\hline \hline
\end{tabular}

This model uses TEM-EDS images as key inputs. A schematic of the model is shown above in Fig. S11. We assume that Rh hemispheres are distributed on the spherical Ag cores. Let us define the following three parameters: $\rho \mathrm{Rh}(\mathrm{Rh}$ density $)=12.4\left(\mathrm{~g} / \mathrm{cm}^{3}\right), \mathrm{DRh}$ (diameter of $\mathrm{Rh}$ hemispheres, in $\mathrm{nm}$ unit), $\mathrm{N}_{\mathrm{Rh}}$ (number of $\mathrm{Rh}$ hemispheres in a given system).

- Given 1 gram of $\mathrm{Rh}_{x} \mathrm{Ag}_{1-\mathrm{x}} \mathrm{NPs}$ ( $\mathrm{x}$ as $\mathrm{Rh}$ content), the total weight of $\mathrm{Rh}$ in the system can be equated as: $N_{R h}\left(2 \pi\left(D_{R h} / 2\right)^{3} / 3\right) \rho_{R h}=x(g)$

- Total interfacial length per gram of catalyst $\left(\mathrm{nm} / \mathrm{g}_{\mathrm{cat}}\right)=\mathrm{N}_{\mathrm{Rh}}\left(\pi \mathrm{D}_{\mathrm{Rh}}\right)$

Plugging (1) into (2), we can estimate total interfacial length as $12 \mathrm{x} / \rho_{\mathrm{Rh}} \mathrm{DRh}^{2}$ (in $\mathrm{nm} / \mathrm{g}_{\mathrm{cat}}$ ).

We used the manually measured diameter statistics (histogram in Fig. S10). The statistical results reveal that the average cluster size increases with Rh content $(0.60( \pm$ $0.20) \mathrm{nm}$ for $\mathrm{Rh}_{13} \mathrm{Ag}_{87} \rightarrow 2.26( \pm 0.53) \mathrm{nm}$ for $\left.\mathrm{Rh}_{50} \mathrm{Ag}_{50} \mathrm{NPs}\right)$. This consequently leads to the decrease of interfacial length with increasing $\mathrm{Rh}$ content. This trend is consistent with the decrease of experimental $\mathrm{H}_{2} \mathrm{O}_{2}$ productivity with increasing $\mathrm{Rh}$ content. Comparing the correlations between productivity and interfacial length (in normalized scale), we noted that productivity of $\mathrm{Rh}_{50} \mathrm{Ag}_{50} \mathrm{NPs}$ is much worse than what is expected from the interfacial length estimation, and this is likely due to the partial alloying in this sample, which further degrades the catalytic activity (Fig. S12). 
$\mathrm{O}_{2}$ dissociation on alloyed $\mathrm{RhAg}$

: (111) surface

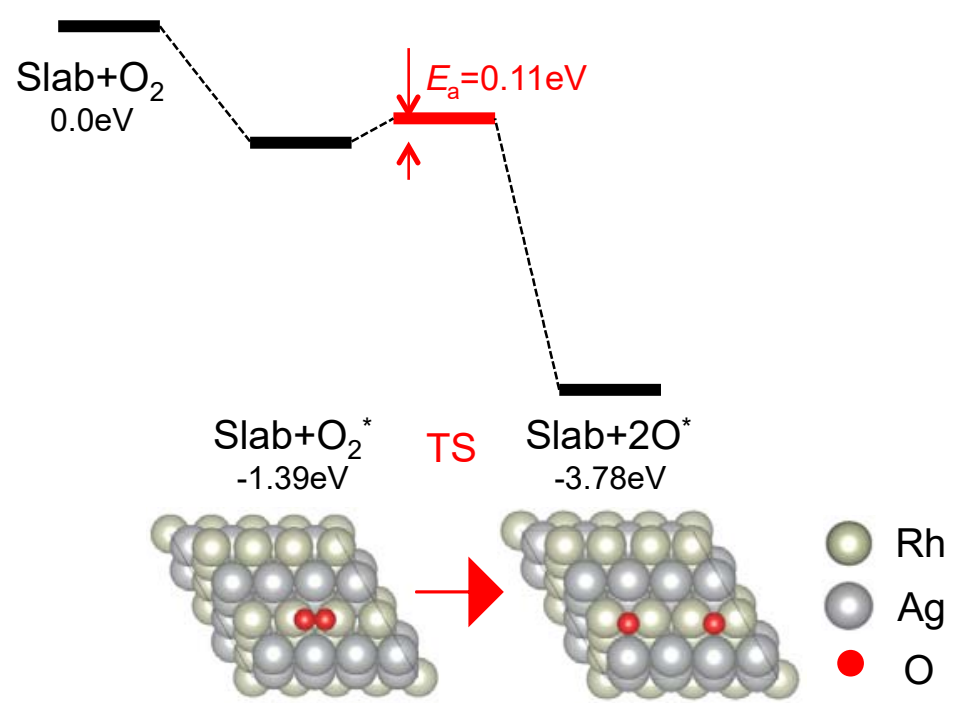

Fig. S14. DFT calculation results of $\mathrm{O}_{2}$ dissociation energetics on the alloyed $\mathrm{RhAg}$ (111) surface. The $\mathrm{O}_{2}$ dissociation barrier on alloyed (111) surface is found very small of $\sim 0.11 \mathrm{eV}$, and thus $\mathrm{O}_{2}$ molecules will easily be broken into $\mathrm{O}$ atomic species, which in turn indicates that $\mathrm{H}_{2} \mathrm{O}_{2}$ productions are highly unlikely to occur on the alloyed surface. These DFT calculations can adequately (at least partially) explain the substantial drop of $\mathrm{H}_{2} \mathrm{O}_{2}$ productivity for the $\mathrm{Rh}_{50} \mathrm{Ag}_{50}$ NPs in which the partial alloying of $\mathrm{Rh}$ and $\mathrm{Ag}$ elements are observed $\left(67.4 \mathrm{mmol} \mathrm{g}^{-1} \mathrm{~h}^{-1}\right.$ for $\mathrm{Rh}_{13} \mathrm{Ag}_{87} \rightarrow 7.53 \mathrm{mmol} \mathrm{g}^{-1} \mathrm{~h}^{-1}$ for $\left.\mathrm{Rh}_{50} \mathrm{Ag}_{50}\right)$. 

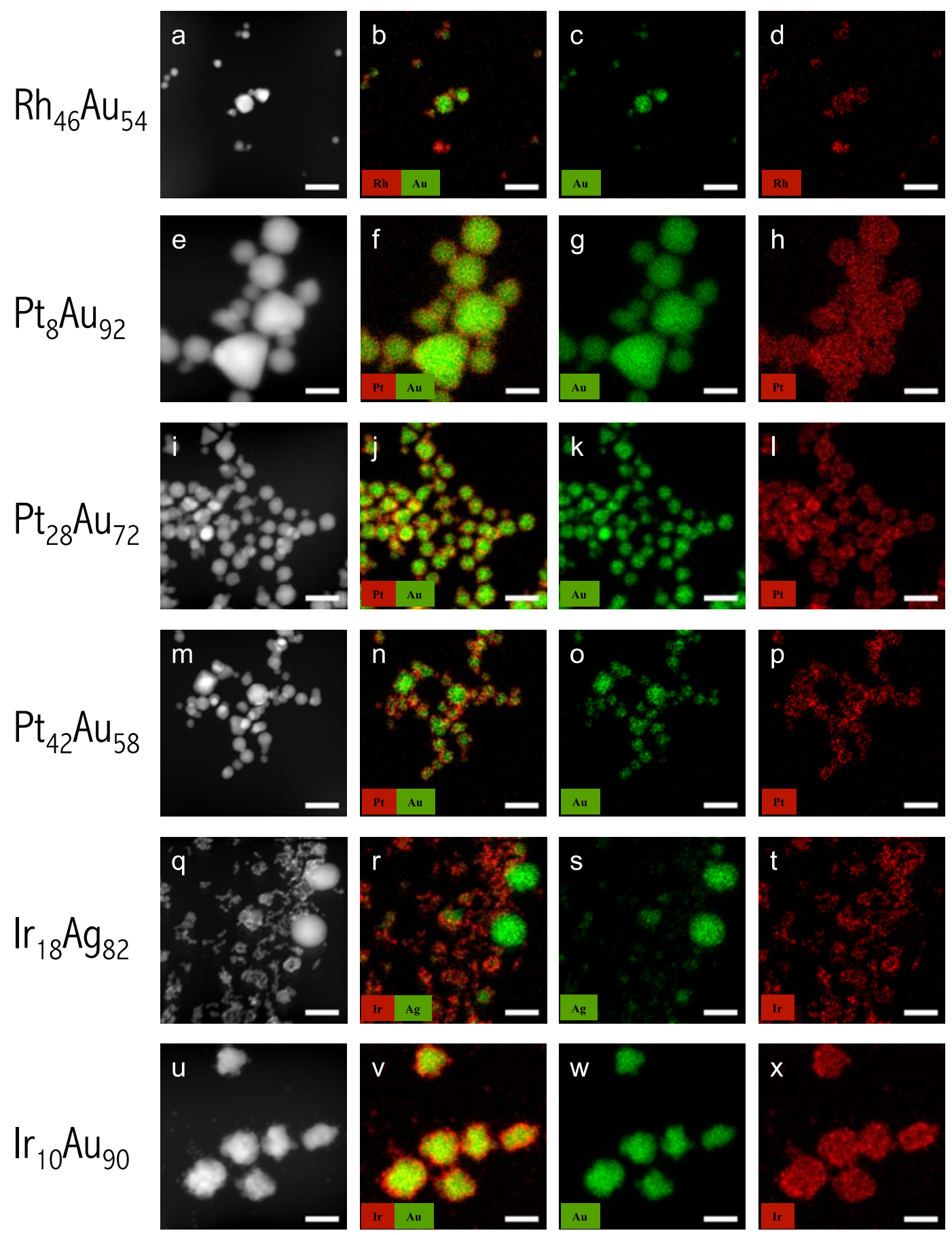

Fig. S15. Structural analysis of the RhAu, PtAu, IrAg, and IrAu NPs. The representative HAADF grayscale image and EDS (RGB) maps of the collective (a-d) $\mathrm{Rh}_{46} \mathrm{Au}_{54}$, (e-h) Pt8Au92, (i-1) Pt28Au72, (m-p) Pt42Au58, (q-t) $\mathrm{Ir}_{18} \mathrm{Agg}_{82}$, and (u-x) Ir10Au90 NPs. Scale bars in the images and maps represent $20 \mathrm{~nm}$. 
a

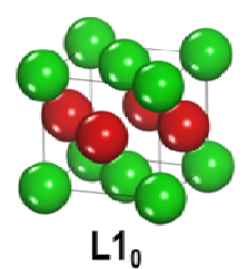

C

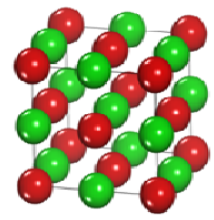

B1

e

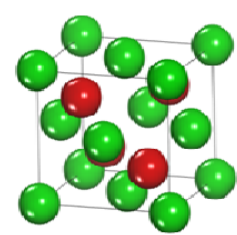

B3

g

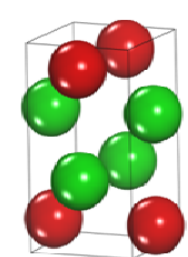

i

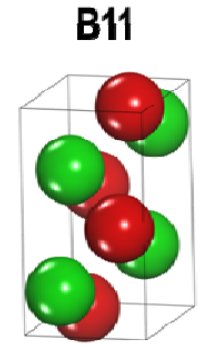

B27 b

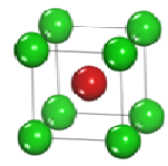

B2

d

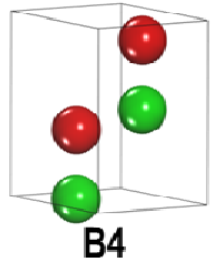

f

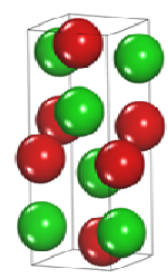

B33

h

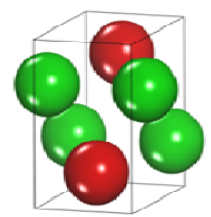

J

\section{B19}

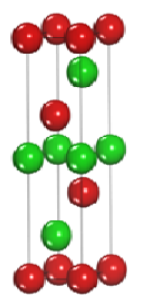

L1

\section{Element A Element B}

Fig. S16. Unitcell crystal structures of 10 possible thermodynamic phases of 1:1 binary alloy. (a) L10, (b) B2, (c) B1, (d) B4, (e) B3, (f) B33, (g) B11, (h) B19, (i) B27, and (j) $\mathrm{L}_{1}$. 


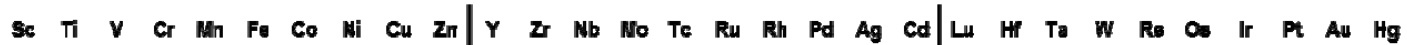

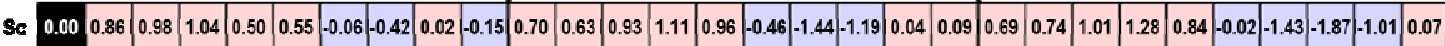

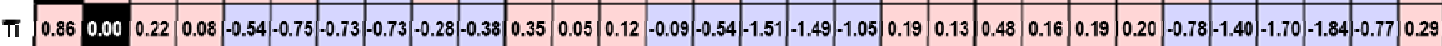

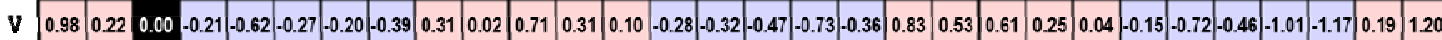

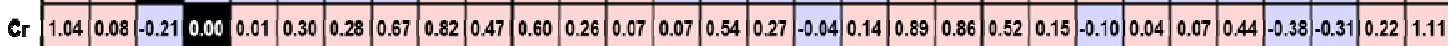

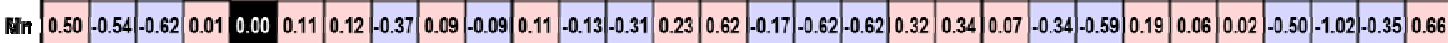

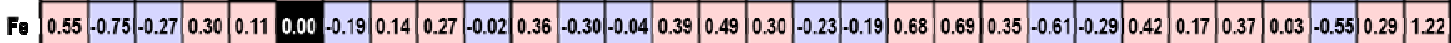

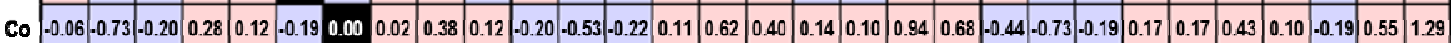

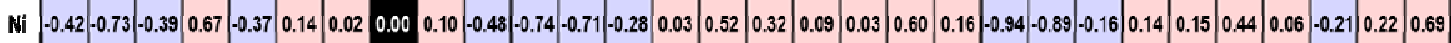

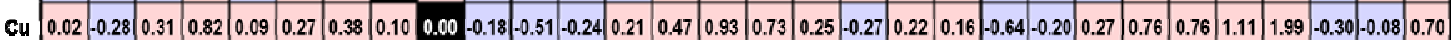

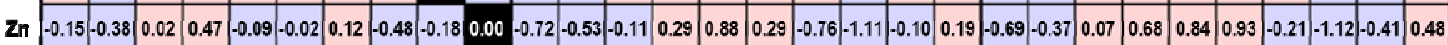

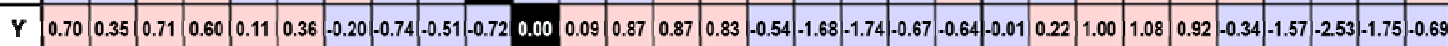

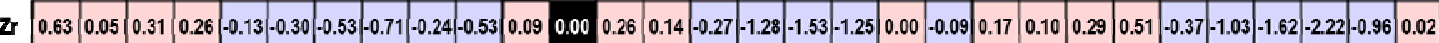

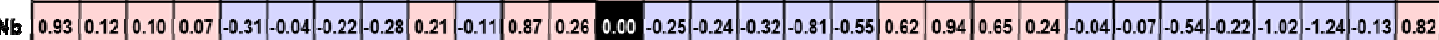

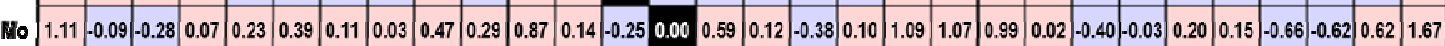

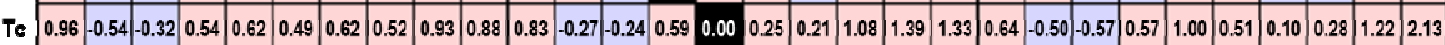

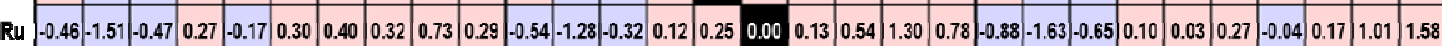

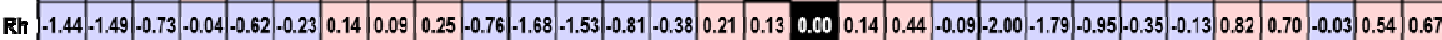

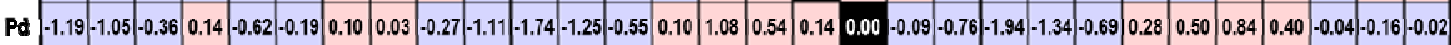

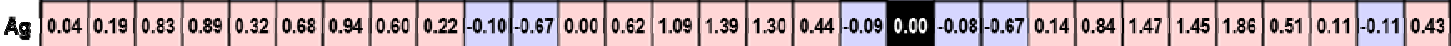

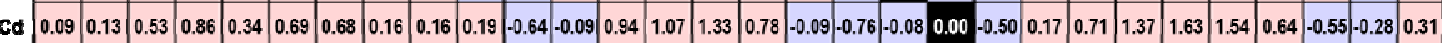

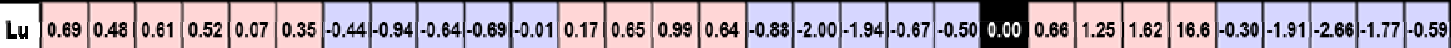

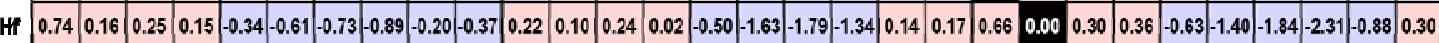

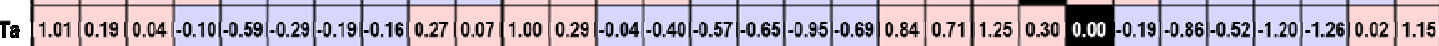

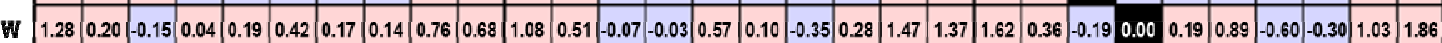

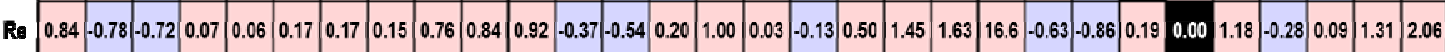

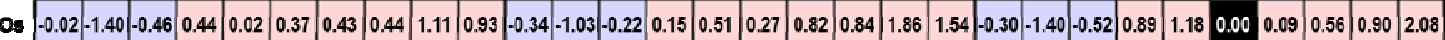

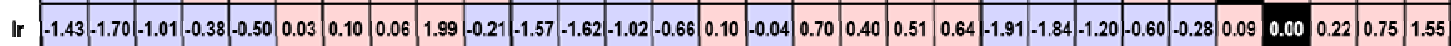

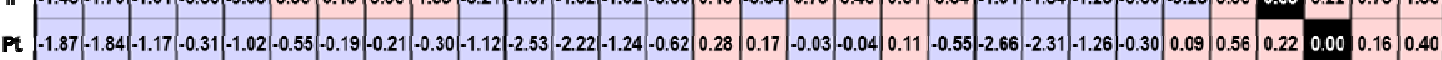

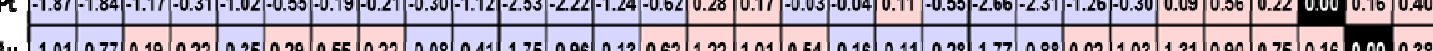

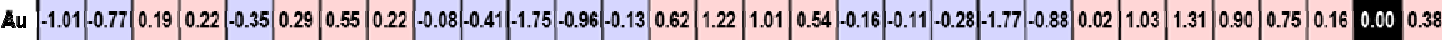

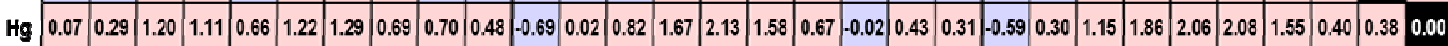

$$
\square: E_{\mathrm{f}}=0 \quad \square: E_{\mathrm{f}}<0 \quad \square: E_{\mathrm{f}}>0
$$

Fig. S17. DFT-computed formation energies $\left(E_{\mathrm{f}}\right)$ of $\mathbf{4 3 5}$ binary alloys composd of two transition metals (in periods IV, V, VI). For each elemental combination, Ef of all 10 thermodynamic phases were compared, and only the most stable phase was presented. Boxes in blue, red, black represent " $E_{\mathrm{f}}<0$ ", " $E_{\mathrm{f}}>0$ ", and " $E_{\mathrm{f}}=0$ ", respectively. 


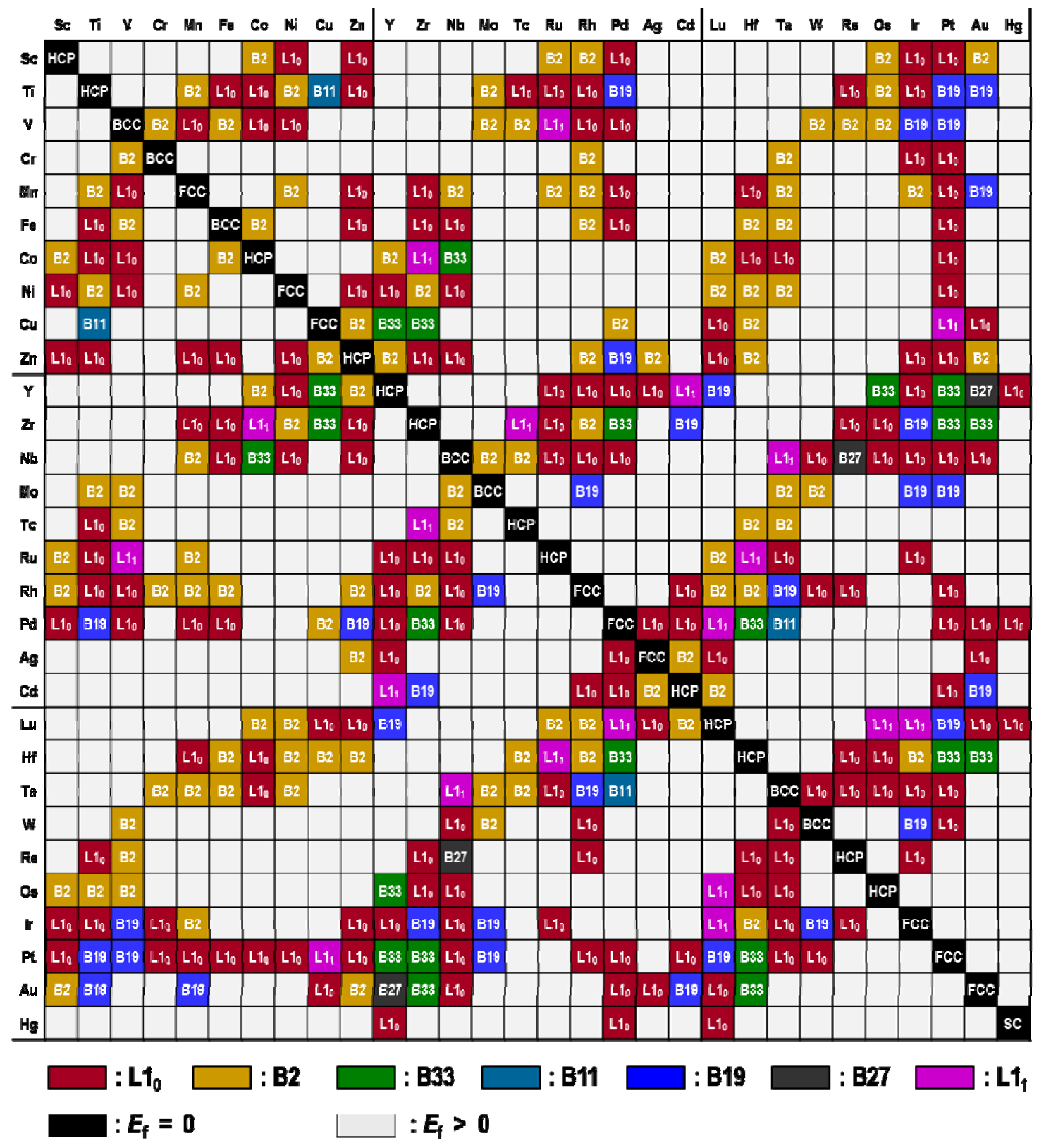

Fig. S18. The most stable thermodynamic phase for 183 miscible elemental combinations (i.e., $E_{\mathrm{f}}<0$ ) as well as pure metals. 
Table S8. The number of elemental combinations in each classified phase for 183 miscible cases, and 252 immiscible ones.

\begin{tabular}{ccc}
\hline \hline \multicolumn{1}{c}{ Thermodynamic phase } & $\begin{array}{c}\text { Number of elemental } \\
\text { combinations }\end{array}$ \\
\cline { 2 - 3 } & AuCu (L1) & $86(20 \%)$ \\
\cline { 2 - 3 } Miscible alloy & CsCl (B2) & $55(12 \%)$ \\
\cline { 2 - 3 } & WuCl (B1) & $0(0 \%)$ \\
\cline { 2 - 3 } & Zinc blende (B3) & $0(0 \%)$ \\
\cline { 2 - 3 } & CrB (B33) & $0(0 \%)$ \\
\cline { 2 - 3 } & CiCu (B11) & $11(3 \%)$ \\
\cline { 2 - 3 } & FeB (B27) & $2(0.5 \%)$ \\
\hline Immiscible alloy & $17(4 \%)$ \\
\hline & Total $(\mathbf{B 1})$ & $2(0.5 \%)$ \\
\hline
\end{tabular}


Table S9. Comparisons of catalytic test conditions (pressure, used catalyst weight, and $\mathrm{H}_{2}$ flow rate) that can affect $\mathrm{H}_{2}$ conversion between ours and selected literatures. Literatures here report a very high level of $\mathrm{H}_{2}$ conversions (almost complete conversions). Cells shaded in gray color signify the more favorable conditions for $\mathrm{H}_{2}$ conversions, compared to our own experiments, i.e. higher pressure, larger catalyst weight, lower $\mathrm{H}_{2}$ flow rate. We observe that experiments were carried out in much higher pressure conditions (>10atm) in two articles of Park et al. and Burato et al. ${ }^{\mathrm{S} 10, \mathrm{~S} 11}$, which highly likely has led to much enhanced $\mathrm{H}_{2}$ conversions. As for the other articles of Samanta et al. and Choudhary et al. ${ }^{\mathrm{S} 12, \mathrm{~S} 13}$, comparatively much larger catalyst weight $(\geq 10 \mathrm{mg})$ or lower $\mathrm{H}_{2}$ flow rate may adequately account for such high conversion values.

\begin{tabular}{l|l|l|l|c}
\hline \hline \multicolumn{1}{c|}{ Materials } & $\begin{array}{c}\text { Pressure } \\
\text { condition }\end{array}$ & $\begin{array}{c}\text { Used catalyst weight } \\
(\mathbf{m g})\end{array}$ & \multicolumn{1}{c}{$\mathbf{H}_{\mathbf{2}}$ flow rate } & References \\
\hline $\begin{array}{l}\text { Our new catalysts } \\
(\mathrm{RhAg}, \mathrm{RhAu}, \\
\mathrm{PtAu})\end{array}$ & $1 \mathrm{~atm}$ & $\begin{array}{l}5-6.5 \mathrm{mg}(\mathrm{RhAg}, \\
\mathrm{RhAu}) ; 1.7 \mathrm{mg}(\mathrm{PtAu})\end{array}$ & $2.0(\mathrm{ml} / \mathrm{min})$ & Not applicable \\
\hline $\mathrm{Pd} / \mathrm{SBA}-15$ & $10 \mathrm{~atm}$ & $\begin{array}{l}1000(\mathrm{total}) \times 0.5 \%(\mathrm{Pd} \\
\text { loading } \mathrm{wt} \%)=5 \mathrm{mg}\end{array}$ & $12.6(\mathrm{ml} / \mathrm{min})$ & {$[\mathrm{S} 10]$} \\
\hline $\mathrm{Pd} / \mathrm{SiO}_{2}$ & $19.7 \mathrm{~atm}$ & $\begin{array}{l}50 \times 1 \%(\mathrm{Pd} \text { loading } \\
\mathrm{wt} \%)=0.5 \mathrm{mg}\end{array}$ & Not available & {$[\mathrm{S} 11]$} \\
\hline $\mathrm{Pd} / \mathrm{SiO}_{2}$ & $1 \mathrm{~atm}$ & $\begin{array}{l}500 \times 2.5 \%(\mathrm{Pd} \text { loading } \\
\mathrm{wt} \%)=12.5 \mathrm{mg}\end{array}$ & $0.7\left(\mathrm{~cm}^{3} / \mathrm{min}\right)$ & {$[\mathrm{S} 12]$} \\
\hline $\mathrm{PdO} / \mathrm{Al}_{2} \mathrm{O}_{3}$ & $0.94 \mathrm{~atm}$ & $\begin{array}{l}100 \times 10 \%(\mathrm{Pd} \text { loading } \\
\mathrm{wt} \%)=10 \mathrm{mg}\end{array}$ & $3.0\left(\mathrm{~cm}^{3} / \mathrm{min}\right)$ & {$[\mathrm{S} 13]$} \\
\hline \hline
\end{tabular}




\section{References}

(S1) Li, J.; Ishihara, T.; Yoshizawa, K. Theoretical Study of the Decomposition and Hydrogenation of $\mathrm{H}_{2} \mathrm{O}_{2}$ on $\mathrm{Pd}$ and $\mathrm{Au} @ \mathrm{Pd}$ Surfaces: Understanding toward High Selectivity of $\mathrm{H}_{2} \mathrm{O}_{2}$ Synthesis. J. Phys. Chem. C 2011, 115, 7392-7398.

(S2) Seo, D.-H.; Shin, H.; Kang, K.; Kim, H.; Han, S. S. First-Principles Design of Hydrogen Dissociation Catalysts Based on Isoelectronic Metal Solid Solutions. J. Phys. Chem. Lett. 2014, 5, 1819-1824.

(S3) Fajin, J. S. C.; Cordeiro, M. N. D. S.; Gomes, J. R. B. On the Theoretical Understanding of the Unexpected $\mathrm{O}_{2}$ Activation by Nanoporous Gold. Chem. Commun. 2011, 47, 8403-8405.

(S4) Xu, Y.; Mavrikakis, M. Adsorption and Dissociation of $\mathrm{O}_{2}$ on $\operatorname{Ir}(111) . J$. Chem. Phys. 2002, 116, 10846-10853.

(S5) Ham, H. C.; Hwang, G. S.; Han, J.; Nam, S. W.; Lim, T. H. On the Role of Pd Ensembles in Selective $\mathrm{H}_{2} \mathrm{O}_{2}$ Formation on PdAu Alloys. J. Phys. Chem. C 2009, 113, 12943-12945.

(S6) Verhallen, P. T. H. M.; Oomen, L. J. P.; Elsen, A. J. J. M. v. d.; Fortuin, J. M. H. The Diffusion Coefficients of Helium, Hydrogen, Oxygen and Nitrogen in Water Determined from the Permeability of a Stagnant Liquid Layer in the Quasi-s. Chem. Eng. Sci. 1984, 39, 1535-1541.

(S7) Edwards, J. K.; Hutchings, G. J. Palladium and Gold-Palladium Catalysts for the Direct Synthesis of Hydrogen Peroxide. Angew. Chem. Int. Ed. 2008, 47, 9192-9198. (S8) Kim, S.; Lee, D.-W.; Lee, K.-Y. Direct Synthesis of Hydrogen Peroxide from Hydrogen and Oxygen over Single-Crystal Cubic Palladium on Silica Catalysts. J. Mol. Catal. A: Chem. 2014, 383, 64-69.

(S9) Kim, S.; Lee, D.-W.; Lee, K.-Y. Shape-Dependent Catalytic Activity of Palladium Nanoparticles for the Direct Synthesis of Hydrogen Peroxide from Hydrogen and Oxygen. J. Mol. Catal. A: Chem. 2014, 391, 48-54.

(S10) Park, S.; Kim, T. J.; Chung, Y.-M.; Oh, S.-H.; Song, I. K. Direct Synthesis of Hydrogen Peroxide from Hydrogen and Oxygen over Palladium Catalyst Supported on $\mathrm{SO}_{3} \mathrm{H}-$ Functionalized SBA-15. Catal. Lett. 2009, 130, 296-300.

(S11) Burato, C.; Campestrini, S.; Han, Y.-F.; Canton, P.; Centomo, P.; Canu, P.; Corain, B. Chemoselective and Re-usable Heterogeneous Catalysts for the Direct Synthesis of Hydrogen Peroxide in the Liquid Phase under Non-explosive Conditions and in the Absence of Chemoselectivty Enhancers. Appl. Catal. A: Gen 2009, 358, 224-231. (S12) Samanta, C.; Choudary, V. R. Direct Formation of $\mathrm{H}_{2} \mathrm{O}_{2}$ from $\mathrm{H}_{2}$ and $\mathrm{O}_{2}$ and Decomposition/Hydrogenation of $\mathrm{H}_{2} \mathrm{O}_{2}$ in Aqueous Acidic Reaction Medium over Halide-Containing $\mathrm{Pd} / \mathrm{SiO}_{2}$ Catalytic System. Catal. Commun. 2007, 8, 2222-2228. (S13) Choudhary, V. R.; Jana, P. Direct Oxidation of $\mathrm{H}_{2}$ to $\mathrm{H}_{2} \mathrm{O}_{2}$ over $\mathrm{PdO} / \mathrm{Al}_{2} \mathrm{O}_{3}$ Catalysts in Aqueous Acidic Medium: Influence on $\mathrm{H}_{2} \mathrm{O}_{2}$ Formation of Pd Loading, 
Calcination Temperature and Reduction of Catalyst and Presence of Halide Anions. Catal. Commun. 2008, 9, 2371-2375. 